\title{
THE HIDDEN GOD: IMAGE AND INTERDICTION IN THE NETHERLANDS IN THE SIXTEENTH GENTURY
}

\author{
DAVID FREEDBERG
}

For Willzam Hood

The sixteenth century was an age of 1conoclasm. Never since the eighth and ninth centuries had images been subjected to so concerted an onslaught as in the century of Raphael and Titian, Durer and Bruegel. Protestant theologians attacked the validity of art itself, and attempted to restrict or redefine its uses. A few wished to do away with all representational images, but the majority were specifically concerned with religious art. Catholıc theologians sprang to the defence of images, using arguments which had been forged in the great Byzantine controversy as well as by authorities who ranged from Gregory the Great to Thomas Aquinas and Bonaventure. ${ }^{1}$ But art was not simply a theological matter, and the use of images was criticized and mocked in countless plays, poems and satires, both in Latin and in the vernacular. Whether spurred on by the symbolic connotations of particular images, or by the wealth they represented, or even by the theological arguments, everywhere men assaulted the images about them. Nowhere did they do so more spectacularly than in the Netherlands in 1566. There iconoclasm raged from the South of Flanders to the farthest regions of Friesland, before burning itself out, all in the space of a few weeks. These are all matters which $I$ have dealt with at some length elsewhere ${ }^{2}$ here the aim is to examine at closer quarters some of the interdictions and prohibitions which arose in the course of the debate about images and as a result of the great iconoclastic outbursts, and then to ask what both phenomena reveal about the status of images in the six teenth century.

'If any abuses creep into these holy and salutary practices, the Holy Synod firmly desires that they be eradicated forthwith. ${ }^{3}$ Thus began the section of the Council of Trent's decree on images. ${ }^{4}$ Although the decree is one of the best known documents in the history of sixteenth-century art, not all of its implications for the history of images have been explored. It was only passed at the final session of the Council, just before Christmas 1563, when the Church's need to formulate an official stand on art had become crucially apparent, not only in the face of ever-mounting criticism, but also as a result of recent outbreaks of iconoclasm in France. ${ }^{5}$ The first half of the decree consisted of a highly traditional justification of religious imagery, but it is the second half 
that we must consider now. There were to be no images of false dogma, the decree insisted, lest the faithful - and especially the illiterate faithful - be led into dangerous erro*. All superstition was to be eradicated in the invocation of saints, the veneration of relics and the use of images; all improper financial gain eliminated; and all lasciviousness avoided. Images were neither to be painted nor adorned with seductive charm. The celebration of saints' days and the visitation of relics were not to be abused by drunken behaviour and junketıng, as if one held such festivals, the Council acerbically remarked, in order to honour the saints by wantonness and revelry. ${ }^{6}$

By 1563 this kind of criticism was commonplace. Indeed, images had been criticized in very sır:ilar terms by both Reformed and Catholic writers. Erasmus, for example, grumbled about the extraordinarily pagan-like character of the processions in which Christian images were carried round ${ }^{7}$ - a criticism, incidentally, which may be judged on the basis of the many surviving prints of such processions (plate 1$) ;^{8}$ and everyone expressed concern about lascivious and indecent images. What the Council of Trent tried to do was to deflect the attacks on images by attempting to remove the abuses associated with them. We will discuss in a moment whether the decree was effective or not; but first let us pursue that matter of interdiction a little further.

Fear of the spread of heresy was the first ostensible motive of the Councll's decree, ${ }^{9}$ and in this respect it should be seen in the context of the great indices of prohibited books which appeared with such regularity throughout the sixteenth century. ${ }^{10}$ Associated with these were the prohibition and censorship of all kunds of theatrical performances, as in the ruthless placard issued by Charles V in the Netherlands on 22 September 1540. That placard, as many others, was directed against 'those heresies which were not yet extirpated and pullulated everywhere'. ${ }^{11}$ But the indices and the placards have received sufficient attention elsewhere, and so, to a lesser extent, have the Italian writers on art like Paleotti, who took up and expanded the Councll's decree on images. ${ }^{12}$ Here I wish to deal at greater length with the situation in the Netherlands, and concentrate on one writer in particular, in order to exemplify some of the general observations to be made later on.

One of the immediate consequences of iconoclasm in the Low Countries in 1566 was the publication of a great spate of treatises justifying the use of religious imagery, largely on the basis of the Tridentine decree. ${ }^{13}$ Most of them simply rehearsed the old arguments, denved largely from the Byzantine writers and a few selected medieval authorities. But there was one writer whose discussion was both more understanding and more thorough than the others, whose influence extended far beyond the borders of the Netherlands, and whose detailed prescriptions reveal an awareness of actual artistic production not paralleled until then by any of the other theological treatises on art. Joannes Molanus was King's Censor, Professor of Theology at Louvain, the author of a number of hagiological works and editor of St Augustine. ${ }^{14}$ His book on religious art - the De Historia sanctarum ımagınum et picturarum - appeared first in 1570 (Louvain), again in 1594 (Louvain), in 1617 (Cologne, Antwerp), 1619 (Lyons), 1626 (Antwerp) and finally in Louvain in $1771^{15}$ - and there can be no doubt that it was widely read. ${ }^{16}$ Let us examine the kunds of imagery 

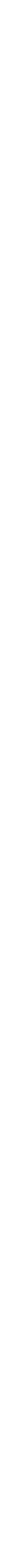

1. After Pieter Bruegel the Elder, The Kermesse at

Hoboken. Engraving published by B. de Mompere, $297 \times$ $410 \mathrm{~mm}$.

2. Jan Massys, Flora, 1561. Stockholm, Nationalmuseum. $130 \times 156 \mathrm{~cm}$.

3. Jan Massys, Judith with the Head of Holofernes. Antwerp, Konnklıjk Museum voor schone Kunsten. $118 \times 80.5 \mathrm{~cm}$.

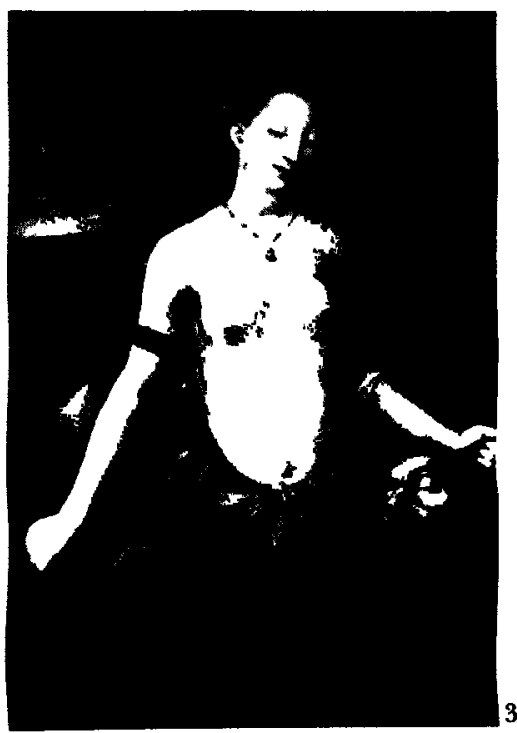



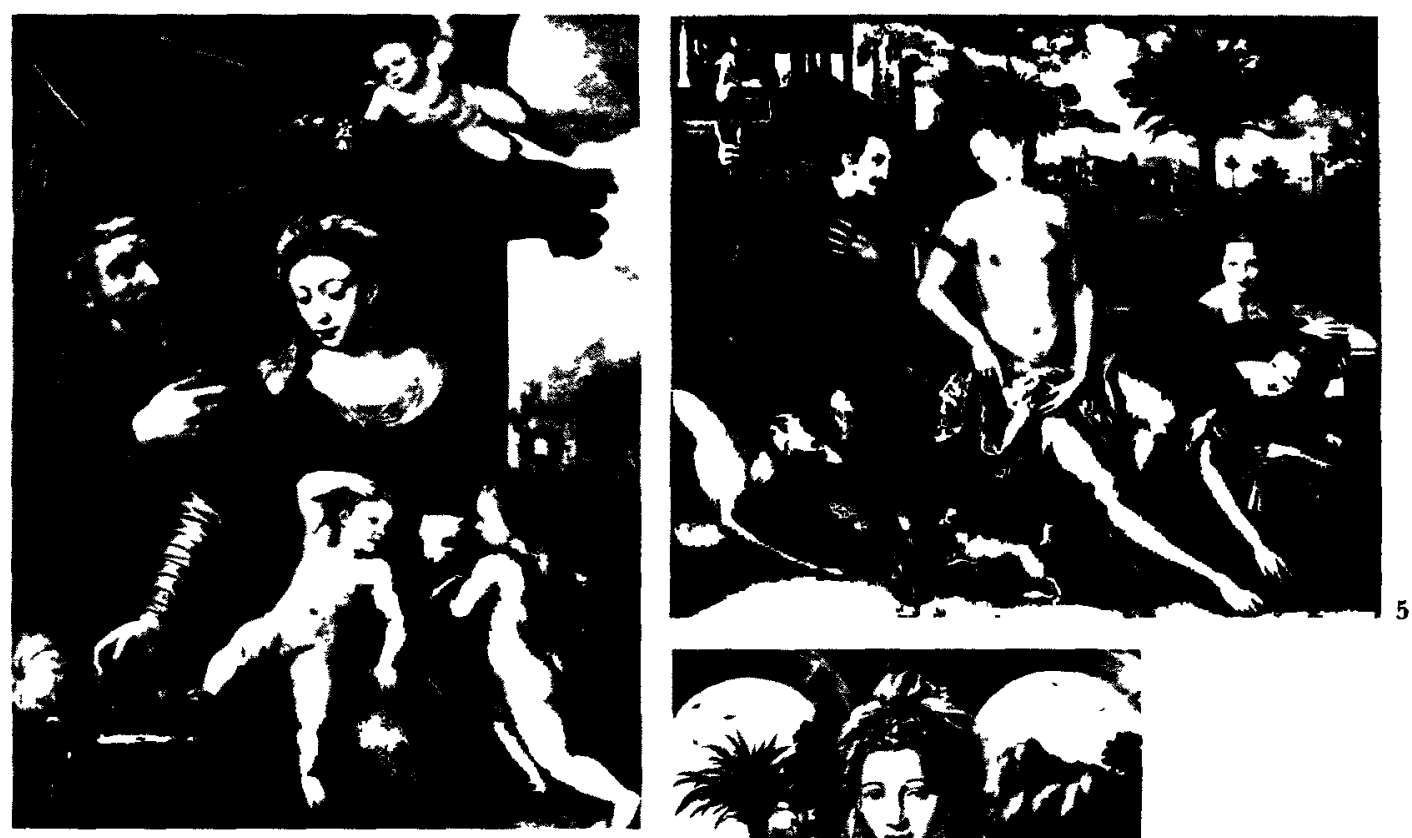

4

4. Willem Key, Holy Family with St John. Whereabouts unknown. $130 \times 100 \mathrm{~cm}$.

5. Jan Massys, David and Bathsheba, 1562. Paris, Louvre. $162 \times 197 \mathrm{~cm}$.

6 Jan Massys, The Magdalene Whereabouts unknown. $101 \times 72 \mathrm{~cm}$.

7. Pieter Aertsen, Christ in the House of Martha and Mary, 1553. Rotterdam, Museum Boymans van Beuningen. $126 \times 200 \mathrm{~cm}$.
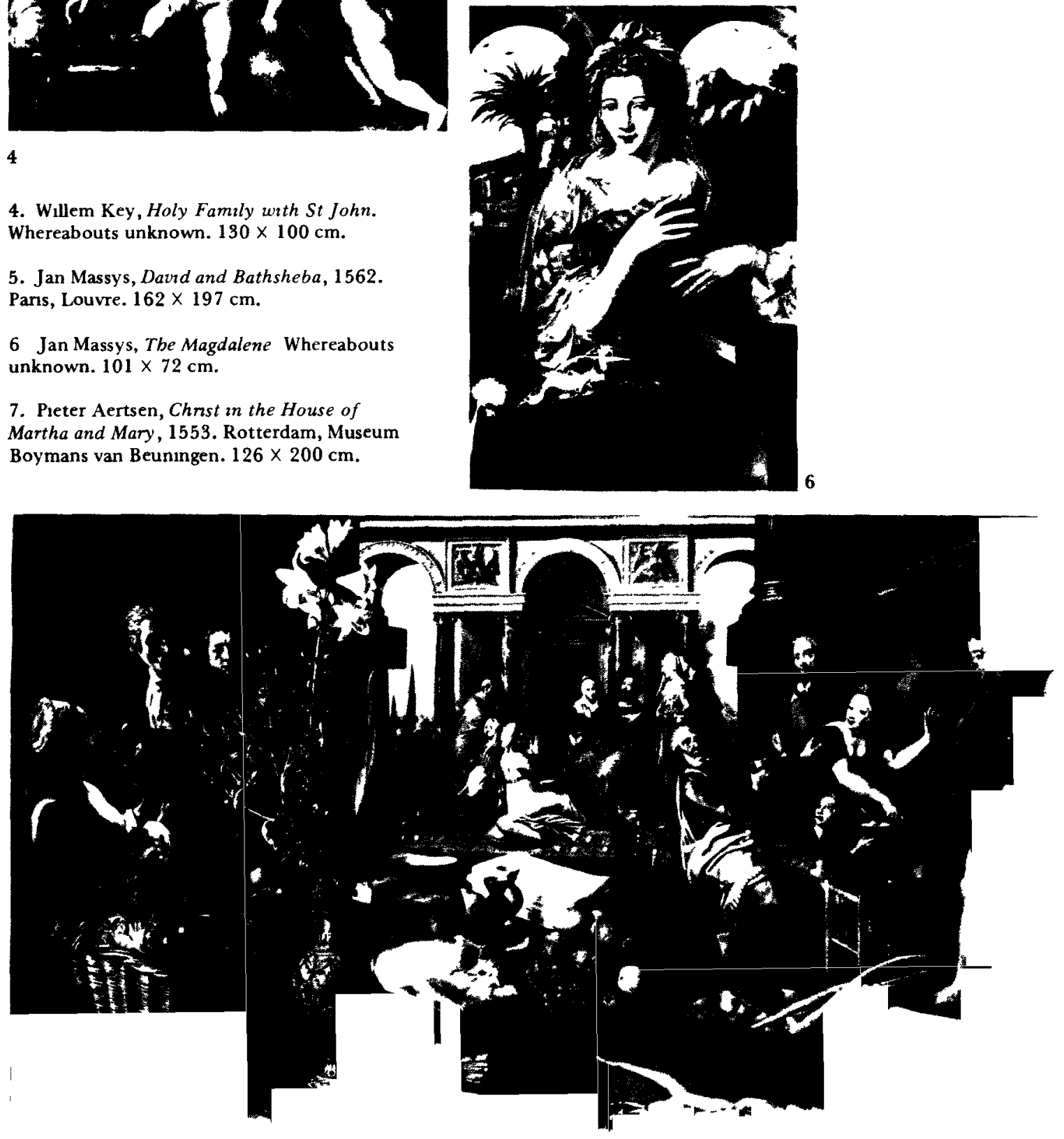
to which he objected. Like almost every other sixteenth-century writer on art, Molanus took up and expanded the Councl's condemnation of lascivious and indecent imagery, but as he was primarly concerned with these problems in relation to religious art, a few words should be sald about attıtudes in the Netherlands towards indecency in the representation of profane subjects. Nudity, needless to say, was the main concern, ${ }^{17}$ and thus we find a whole variety of writers, from the poetess Anna Bijns to the theologian Martın Donk, phrasing their objections in a way which also served - they thought - to undermine the Protestant stance on images. Why, they asked, did iconoclasts do away with images of Christ and the saints instead of strange histones and pagan narratives? They destroyed what inspired devotion but not what roused unchastity. In their own homes they had unedifying and immoral representations of Lucretia, Venus, and other female goddesses. ${ }^{18}$ The kind of picture we can imagine such writers were referring to may be represented by Jan Massys's evidently popular portrayals of female nudes (plates 2 and 3); $1^{19}$ works like these reached the height of fashion in the half-dozen years immediately preceding iconoclasm. ${ }^{20}$ But for Molanus the depiction of a holy subject in an unedifying way was still worse. Not only did he go so far as to proscribe the representation of the naked Christ Child (lest children, above all, be corrupted) (plate 4$),{ }^{21}$ he also felt that it was unnecessary to show David luring Bathsheba into Adultery, the Dance of Salome, or even the Magdalen unchastely represented in her pre-conversion state as a woman of the world, instead of as a penitent (plates 5 and 6$).{ }^{22}$ Here, of course, one has also to do with the notion of decorum, and one moves away from the field of expressly lascivious imagery - though most of these images were certainly that too. Molanus went to some length to ensure that sacred subjects were not represented in an indecorous manner. Like Erasmus he objected to the representation of St Peter red-faced from the effects of too much drink in paintings of Christ in the House of Martha and Mary, ${ }^{23}$ such as those which were produced on several occasions by Pieter Aertsen and Joachim Beuckelaer, in Molanus's lifetıme (plate 7; cf. plate 8). ${ }^{24}$ Details such as this were proscribed not merely because they were indecorous, but for another reason: there was no reference to them in the Bible. Although it is often claimed that the Councll of Trent expressly forbade all subjects of an apocryphal or non-canonical nature, the only specific objections are to images of 'false dogma,' and to those regarded as 'contrary to custom' or 'unwonted' (insolitae). ${ }^{25}$ But writers like Molanus - and Paleotti later on - were to expand this concern into a wide-ranging and critical review of all subjects for which there was no firm canonical or histoncal basis. The detailed enumeration of traditional subject-matter in both Molanus and Paleotti provides evidence of the extent and depth of their critique; but Paleottı never got round to completing or publishing his third, fourth and fifth books (though the detailed table of contents which survives gives some idea of what he planned to include in them). Molanus's thorough investigations, on the other hand, were to be the most influential of all the post-Tridentine theological writers; and it is he who reveals most clearly the tension between stricture and practical exigency that characterizes many of the phenomena we will be describing.

He deplored the representation of midwives at the Nativity - as had long 
been depicted in paintıngs like Campın's Nativity in Dijon - on the grounds that their inclusion was based on the apocryphal book De Infantra Salvatoris; ${ }^{26}$ like several others before him he did not wish to have the Virgin shown dying on her sickbed because she died, just as she had given birth, without any pain $; 27$ and he went to quite extraordinary lengths to demonstrate why it was wrong to represent the third magus as black, in paintings of the Adoration of the Magi (plate 9) ${ }^{28}$ Finally, there was a class of imagery which was not only uncanonical, but could also be seen as a kind of threat to received dogma. Amongst such images were those which showed Christ in the form of a homunculus descending amongst the rays to the Virgin in paintings of the Annunciation (as in the central panel of the Mérode altarpiece in New York) (plate 10), ${ }^{29}$ and pictures of the Resurrection where the cover of the sarcophagus was removed (cf. plate 11$)^{30}$ on the grounds that the miracle of the event consisted precisely in the fact that Christ had risen from the closed tomb. ${ }^{31}$ Fifteenth-century works as well as contemporary ones have deliberately been chosen to illustrate the kinds of subjects which Molanus wished to proscribe. They testify not only to his awareness of the art around him - a rare enough phenomenon amongst the theological writers on art - but also to the strength of certain pictorial traditions. In this respect, as will become apparent, Molanus was tilting at windmills.

But there was another, more tolerant side to Molanus. Amongst the subjects to which he objected but which he thought could be tolerated were, for example, the Seven Joys and Seven Sorrows of the Virgin (plates 12 and 13). ${ }^{32}$ Though apocryphal, such subjects were harmless and too firmly rooted in popular tradition to be easily eradicated, as Molanus himself acknowledged. ${ }^{33}$ For similar reasons he was prepared to allow representations of St Christopher carrying the Christ Child or of the Apostles surrounding the Virgin's tomb in paintings of the Assumption of the Virgin - despite the fact that they were apocryphal too. ${ }^{34}$ Popular prints showing the wounded hands, feet and heart were also permissible, on the grounds that they inspired devotion and could be used for salutary meditation. ${ }^{35}$ These examples are mentioned here to show that despite his apparent censoriousness, Molanus was prepared to display a quite unusual degree of tolerance. Indeed, he remunded his readers that those who squeeze too tightly draw blood - Nam qui nimium emungit elicit sangurnem. ${ }^{36}$ But at the same time these broadminded sections of his work serve to emphasize the extraordinarily careful and comprehensive nature of Molanus's criteria for prohibition and censorship.

This listing has exemplified only a few out of the vast set of rules provided by Molanus, and those familiar with the Italian writers on art will recognize at least some of them, and be able to add many others. One thing, however, is clear. Hardly any of these attempted interdictions can be said to have been successful; several of the illustrations reproduced here serve as a demonstration of that. Indeed, even the official interdictions - against books, music and theatre as well as against paintings - were notoriously ineffective. In most cases established pictorial traditions and iconographic habits were simply too strong; and the fact that particular restrictions falled to apply to those who were above them - like Philip II himself - can hardly have helped to weaken the 

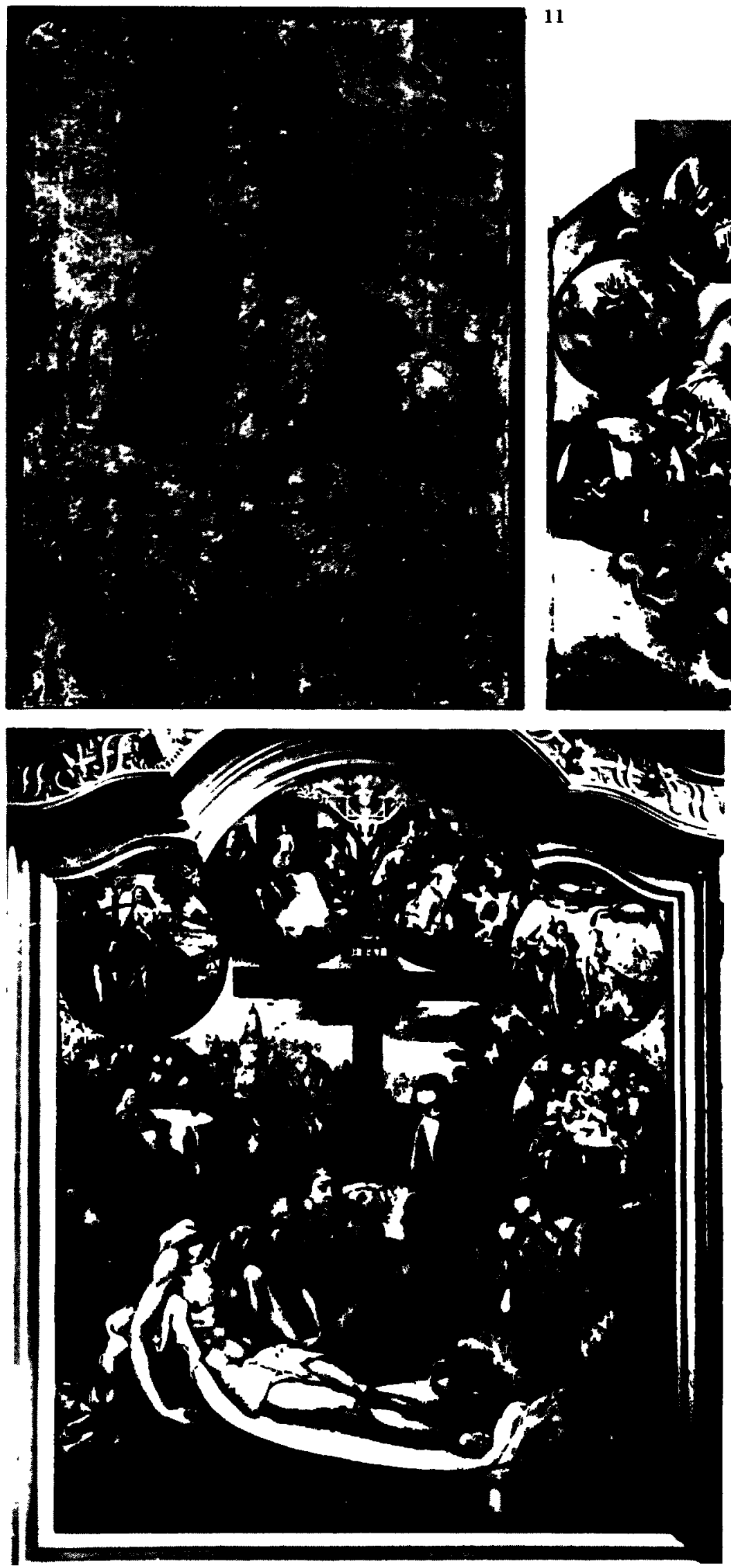

11. Pieter Bruegel the Elder, The Resurrection. Rotterdam, Museum Boymans van Beuningen Pen and brown ink with grey wash $431 \times 307 \mathrm{~mm}$

12. Preter Aertsen, The Seven Jow of the Virgin. Zoutleeuw, Church of St Leonard. $175 \times 140 \mathrm{~cm}$

\section{Pieter Aertsen, The Seven} Sorrows of the Virgin. Zoutleeuk Church of St Leonard. $210 \times 185$ cm. 
survival of customary forms of representation. But how is it that - contrary to what one might expect - the arguments of the Protestant writers against images often provided a direct impulse to iconoclasm, ${ }^{37}$ while the prohibitions which Catholic theologians wished to introduce had so little effect? Admittedly attempts were made to cover up the nudities in the Sistıne Chape ${ }^{38}$ and one finds an occasional artist like Ammanatı, who expressed his remorse at having sculpted lascivious figures in his rash youth. ${ }^{39}$ But these are exceptions rather than the rule.

Historians of art may feel that there is a relatively simple answer to the question of why so many interdictions fall to work. Artistic styles, modes and fashions cannot be made to change at the whim of a theological decision; whatever theologians may say, artists themselves are - by and large - more concerned with aesthetic matters than the intricacies of orthodox dogma. Thus, when confronted with complaints about the heretical ideas contaned in Botticinı's (?) Assumption now in the National Gallery in London, Vasarı simply dismissed the problem by saying that 'As to whether this is true or false, I cannot be expected to judge; it is enough that the figures painted therein ... are entirely worthy of praise ... all varied in diverse ways and the whole executed with good design' $;{ }^{40}$ while an amusing story about Toto del Nunziata betrays a wry - and sophisticated - awareness of the fact that the fault lay as much in the mind of the beholder as in the artist's intention. When a citizen once confessed to him that certain painters displeased him because they only treated lascivious subjects, and then went on to say that he wanted a Madonna which should be modest and not an incitement to desire, Nunziata painted him one with a beard. ${ }^{41}$ Artists had little choice in the matter. The fashion, or rather the mode, was to paint charming Madonnas, and there was plenty of scriptural authority for her beauty. Even if one wanted to, one was hardly likely to paint stern and forbidding Virgins: they simply would not have sold very well.

But all this is begging the question. The fact is that interdicions were formulated and artists expected to submit their works to rigorous ecclesiastical supervision. Following the promulgation of the Tridentine decrees, church officials insisted on seeing preliminary designs for new altarpleces, and periodically visited artists' studios in order to ensure that their stipulations and requirements were not infringed. ${ }^{42}$ For a long time afterwards, the Church visitors made the rounds of the parish churches, insisting on alterations to indecorous imagery in one place, and the eradication of superfluous or aberrant imagery in another. But even this kind of control seems to have been largely ineffective. ${ }^{43}$ Only once one has established why interdictions arise in the first place, and what their motives are, can one begin to see the fundamental reasons for their success or failure. First we should attempt to define the function of the interdictions enumerated here and then examine more closely the relationship between their intended purpose and their actual effect.

In general terms, the sixteenth-century rules were intended to counter and weaken Protestant charges against images: by removing the abuses associated with religious art, Catholic theologians hoped to eliminate those aspects which offended the critics. But the charges were more substantial than that, and 
required, as we shall see, a more basic defence of the validity of images. At this point it should be made clear that we are seeking the social origins of these interdictions, and attempting to define their role and function in the particular society we are consıdering. I have, in short, borrowed from Durkheim in replacing the ethnographer's taboo - in any case a much debated term - with the less specific term of interdiction. ${ }^{44}$ Interdictions are simply an embodiment of that which is forbidden - rather than that which is prescribed - in a particular social group. ${ }^{45}$ They have two main objects: first, to separate different classes of the sacred, and second - and more significantly - to separate the profane from the sacred. Both aspects of interdiction arise from a collective awareness and acknowledgment of the sacred..$^{46}$ Let us see how this applies to the prohibitions we have been considering.

The relative tolerance extended to paintings of subjects such as the Sorrows and Joys of the Virgin, or St Christopher, for example, represents the separation of different classes of the sacred $;^{47}$ and the fact that vanous attempts were made to diminish the importance of the representation of saints and to confine them to the side panels of triptychs and polyptychs is further testimony to this kind of interdiction. For the rest, however, the interdictions - whether attempted or real - are to be seen in terms of the separation of the sacred from the profane. This applies, for example, to the rule about processions: Holy images were not to be carried about or saints' days celebrated as if they were profane feasts or heathen ceremonies. ${ }^{48}$ There is an unspoken awareness and concern here about the fact that many of the religious festivals grew out of much older pagan rites, though it is perhaps best not to press the point too far. Sacred subjects should not be represented as profane ones. Even the concern about nudity in art may be seen in these terms. Ostensibly, nudity may have been forbidden because of the fear of carnality; but there was possibly another reason. The statues and subjects of pagan antiquity were represented as nude forms, as Clement of Alexandria knew as well as Molanus, ${ }^{49}$ and one needed to avoid all possible confusion with that, in order to ensure that the distinction between Christian sacredness and pagan profanity did not become blurred. But the profane was not only to be equated with the remains of non-Christian rites and customs. It was also necessary to maintain the distinction between the everyday and the sacred. Here hes the root of many of the interdictions to be found in the sixteenth century - including, for example, the concern about representing the Virgin suffering in childbirth or dying on her sickbed in the way ordinary women do. This is the root of the recurrent objections to painters like Caravaggio who appear to confuse the everyday with the sacred.

Now all this may seem fairly obvious, and I am aware that the Durkheimian distinction between sacred and profane has been charged with being too blunt to be serviceable. We will in fact modify it later, but the nature of these interdictions has been rehearsed at some length because they all imply one thing: a recognition, however confused, of the polarity of the sacred and non-sacred. At the same time, they bear witness to the contagiousness of the sacred, to the tendency of what is regarded as sacred to be carried over into apparently non-sacred objects and to leave its traces there. This is one of the reasons for the fear, articulated by the theologians, of so wide a range of visual 
imagery. It is obvious that the profane may contaminate the holy, but sacred contagion is just as significant, and is more or less inevitable; both factors, as we shall see, account for the relative ineffectiveness of the interdictions we have been considering. Here we move one step closer towards an understanding of the status of the image in the sixteenth century; but first we must ask ourselves what the image itself was supposed to be, not merely the subject or its material and physical form, but the image as a whole; not signified or signifier, but the sign itself. The Council of Trent's decree on images again provides a starting point.

The decree began with an assertion of the value of invoking the saints and venerating their relics; only then did it give the reasons for retaining images in churches and for honouring and worshipping them. It is the first of these reasons that must concern us here. Images were to continue to be venerated not because any divinity was believed to inhere in them, nor because of any particular virtue for which they might be worshipped, nor indeed because one sought anything from them, or placed one's faith in them, as the heathen used to do when they placed their faith in idols. One worshipped and venerated images because the honour pard to them passed on to the subjects they represented. ${ }^{50}$ The decree then went on to restate the value of images in instructing the people and reaffirming their faith, ${ }^{51}$ in terms derived indirectly from Gregory the Great,$^{52}$ Bonaventure and Thomas Aquinas; ${ }^{53}$ but it is the passage taken out of context from St Basil, that the honour pard to an image passes to its prototype, which is crucial. ${ }^{54}$

One of the commonest forms of the Protestant criticism of images was that in venerating them one merely venerated inanimate pieces of wood and stone $;^{55}$ the official Catholic response, therefore, was. No, it is not the wood and stone that we worship, it is what the images represent. In these two opposing standpoints one finds the theological expression of one of the basic questions about the nature of images in the sixteenth century. The present task, however, is not to determine what the ritual status of images was supposed to be, but rather what it actually was. Here we are treading on difficult ground. In the first place it is clear that the theological arguments had a specific polemical function, and cannot therefore provide a guide to the nature of men's response to images. Although the Protestant argument has some element of truth in it, it really is rather specious. However splendid the material objects were (and in this respect Martin Luther made similar critıcisms to St Bernard),${ }^{56}$ men worshipped them only because they represented something else, something holy. The Catholic rebuttal, on the other hand, has all the air of an academic distinction: Is it likely, we may ask ourselves, that the countless men who went on pllgrimages to particular images, who sought ald from a favourite painting or sculpture, or who went to be healed by the miracle-working powers of a specific shrine made this kınd of distinction? All the evidence suggests not. They expected such things not simply from St Anthony or the Virgin, but from specific physical embodiments of them, from a St Anthony in a favoured chapel, from the Virgin at a renowned pilgrimage shrine. In all ages men have tended to fuse image and prototype, to attribute the powers of the signified to the sign itself. But why is this so, and what are the implications for the study of the art of a 
particular period, in our case the six teenth century? The totem, to put it in Durkheimian terms again, is above all a symbol of something else $;^{57}$ and the sentiments something arouses in us spontaneously attach themselves to the symbol representing it. Thus it comes about that it is the image of a saint which works miracles or exercises power; not the saint himself, but the saint in or workıng through a particular image. This is the fusion of image and prototype just referred to, and this is why all images retain traces of the life, in the sense of the anima, of the signified. Under certain conditions, as in the countless medieval miracle legends, such as those by Caesarıus von Heisterbach and Gautier de Coincy, ${ }^{58}$ images may actually come alıe; men destroy images not only because they are symbols of a rejected or hated or repressive order, but because they feel that by destroying them they somehow break or diminish the power of the images concerned. Hence the mutilation of statues by the removal of their most vital parts, their arms, legs or heads $;^{59}$ or the eradication of that which expresses their lifelike quality most of all, their eyes. Here a cautionary note may be added: I am not say ing that by destroying or mutilating a painting or sculpture one somehow damaged the being it represented, by a magical or any other kind of process. All that is being suggested is that such actions sought to diminish the particular power of an image.

But what is the connection between the animism of images and the interdictions with which this paper began? In his Natural History of Religion, Hume accounted for the attribution of life to inanimate objects by saying that 'there is a universal tendency among mankind to conceive all beings like themselves, and to transfer to every object those qualities with which they are familiarly acquainted, and of which they are intimately conscious ${ }^{, 60}$ - a passage which was also quoted by Freud in his discussion of animism in Totem and Taboo. ${ }^{61}$ Now all this seems self-evident, but it is precisely the tendency to transfer qualities with which men are familiar that blurs the distinction between sacred and profane, between the holy and the everyday, the numinous and the physical. We have already seen how the basis of the Catholic interdictions lay in the need to preserve this distinction, but the same need also informs one of the best-known and most emphasized of the Protestant interdictions: that of the prohibition against representing God in human form. One of the most remarkable of the many examples to be found of the kınd of censorship which resulted from this prohibition is represented by the alteration of engravings after Marten de Vos, as exemplified by the transformation illustrated in plates 14 and $15 .^{62}$ It is common enough to find paintings or engravings where the figure of God the Father has been covered over, but the alteration of the copper plate itself is more unusual, and provides a striking instance of the attempt to preserve the sacredness of the divine by stripping it of every possible human - and therefore profane - reference. The transfer of qualities with which we are familiar to an object, as described by Hume, has no possibility here. God is not objectified at all - he has been replaced by a radiant emptiness, filled not by an image but by words. The human and the physical has been supplanted by the numinous, by the obviously sacred. But in the mutilation of the tragic sheet illustrated in plate $16,{ }^{63}$ one is dealing with a somewhat different phenomenon (whether it was cut up at the end of the sixteenth century or later does not really matter). This 


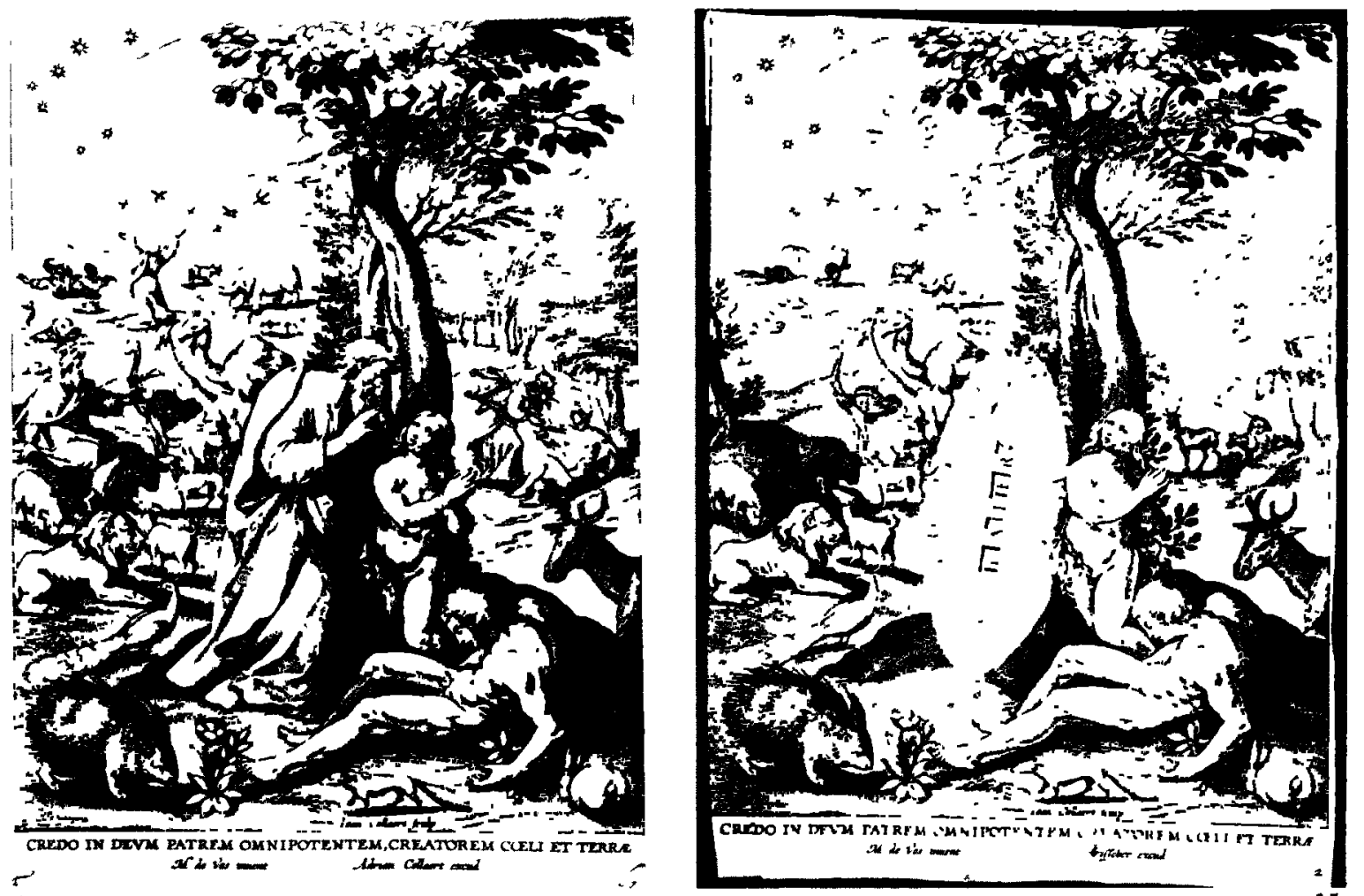

14 J. Collaert after M. de Vos, The Creation of Eve. Engraving published by \& Collaert

$15 \mathrm{~J}$ Collaert after M. de Vos, The Creation of Eve. Engraving, altered plate publshed by C. Visscher

16 J Collaert after J Snellinck (?), The Seven Days of Creation. Mutllated engraving. Pepys Lubrary, Magdalene College, Cambndge

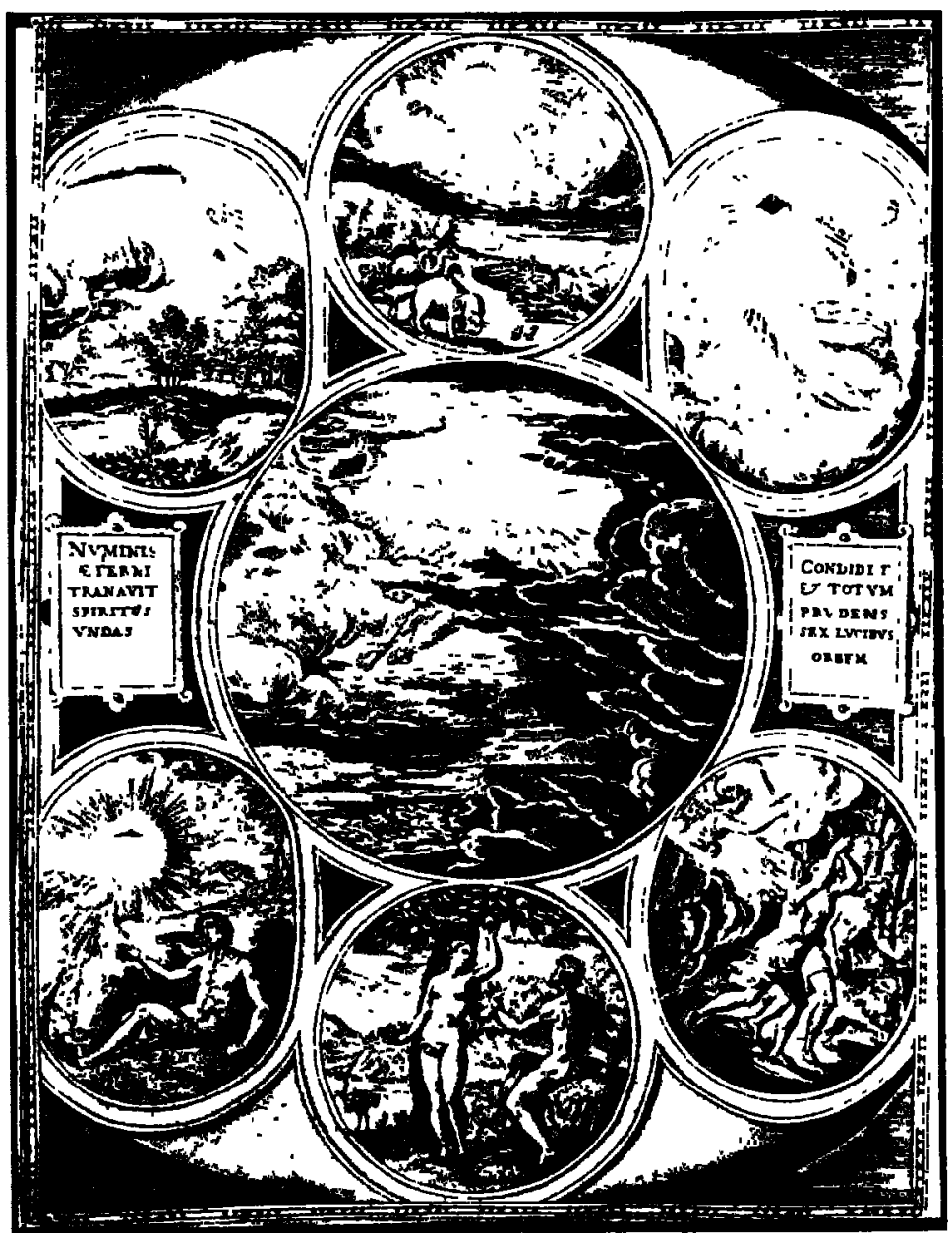




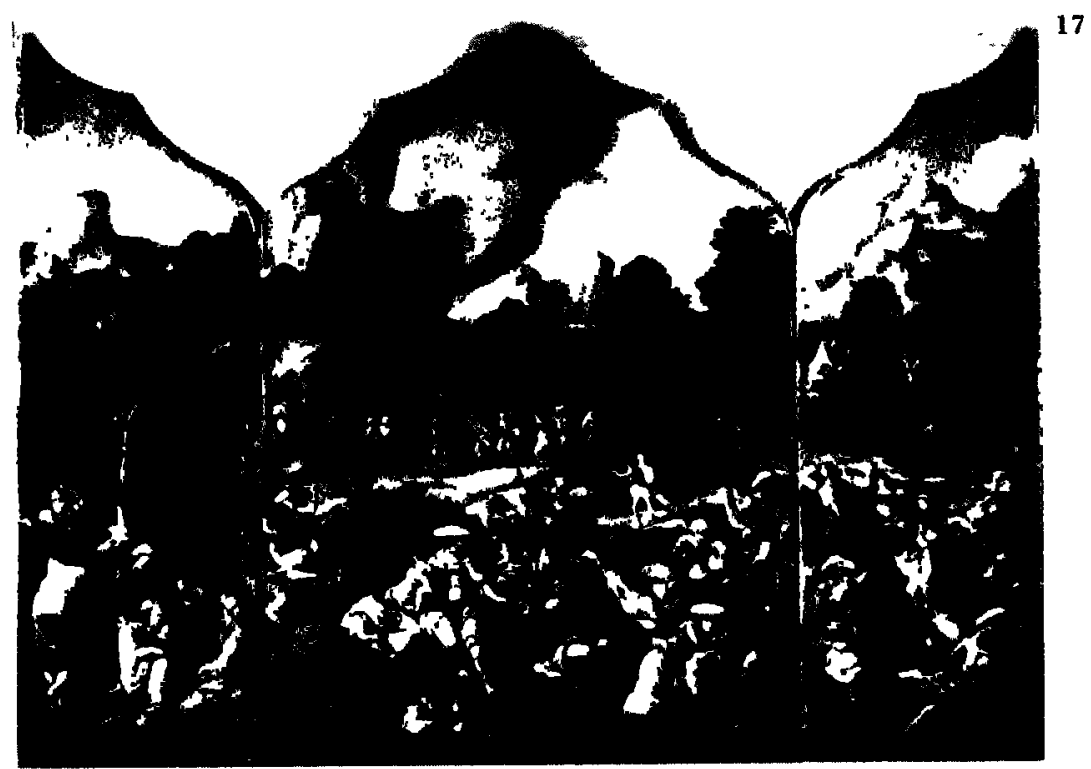

17. Lucas van Leyden, The Adoration of the Golden Calf. Amsterdam,

Rijksmuseum. $93 \times 67 \mathrm{~cm}$., wings $91 \times$ $30 \mathrm{~cm}$.

18. J. Patınır, St Chrstopher. Esconal, Museos Nuevos. $127 \times 172 \mathrm{~cm}$.

19. Joachım Beuckelaer, Vegetable Market with Ecce Homo. Stockholm, Natıonalmuseum. $123 \times 165 \mathrm{~cm}$.

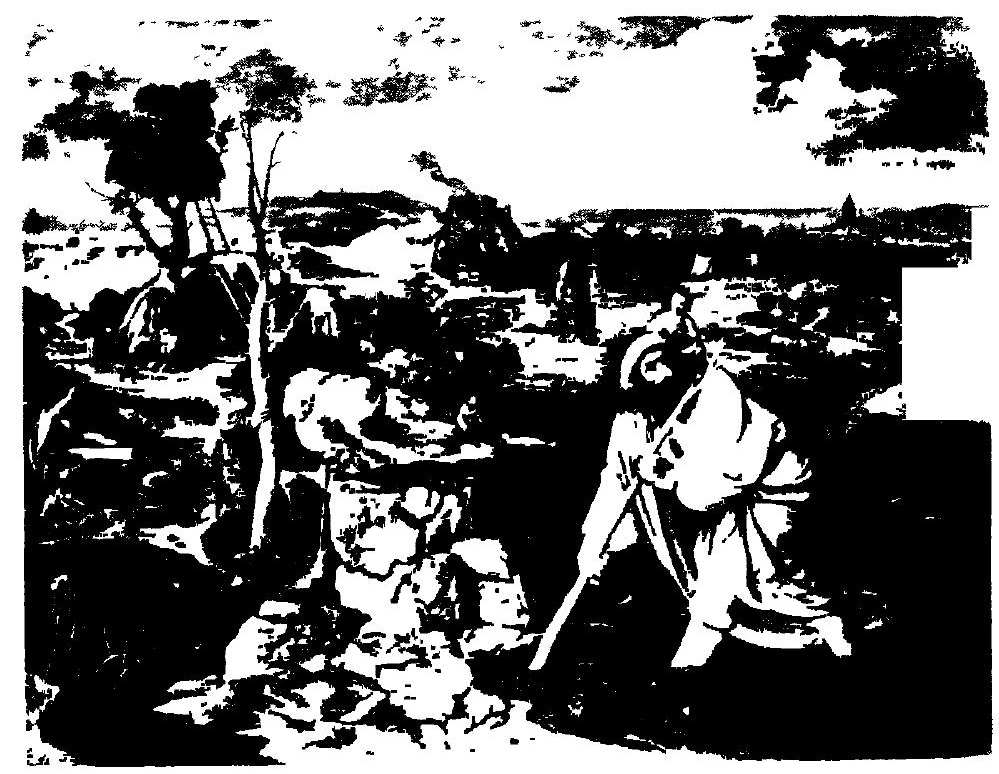


is the point at which interdiction becomes iconoclasm. The mutilation is not merely an instance of the objection to showing God the Father in human form; it is an attempt to deprive the image of its very life. Fear of the power inherent in an image is at least one of the reasons for its destruction. All images, even apparently secular ones, retain something of the powers associated with their subjects. It is the recognition of this that leads on the one hand to the elaboration of a system of interdictions, and on the other to iconoclasm.

It has been suggested that almost every interdiction arises from the need to separate the sacred from the profane. But here one confronts a problem that is implicit in the whole discussion presented here. By what criteria may one distinguish between the sacred and the profane? The question arises not only because many of the interdictions appear to have falled precisely because of the variety and potential variability of the criteria, but also because it rases some of the basic methodological issues at stake in any study of the place of images in society. Perhaps, it will be argued, one has to define more precisely the kinds of images to which the interdictions were supposed to apply. Did they apply only to altarpieces in public places, or to all paintings with religious subjects? Did they extend to secular imagery? Was the purely narratival less important from the point of view of the interdictions - than the intentionally devotional? But these questions do not resolve themselves very easily. There are many cases from the sixteenth century where the matter seems ambiguous What is one to make, for example, of Lucas vail Leyden's Triptych of the Golden Calf (plate 17), where the narratival function seems to replace the religious function; ${ }^{64}$ of paintings like Patınır's St Christopher which seems nothing more than a pretext for a landscape (plate 18); ${ }^{65}$ of Joachım Beuckelaer's Market Scene with Ecce Homo (plate 19) where the market scene seems more important than the religious one, explicitly hidden in the distance ${ }^{66}$ and of Bruegel's 1565 Woman Taken in Adultery (plate 22) ${ }^{67}$ where the real meaning is possibly implicit and in this sense hidden? ${ }^{68}$ And, perhaps more importantly, what would those who formulated interdictions have made of such pictures?

It may all seem a matter of function, and we may think that the problem of definition resolves itself once we have established the ritual function of the painting concerned, or whether it hung in a private house or in a church, in a tavern, a town hall, or a chapel. But unfortunately the matter is not as simple as this. Even of one establishes - to take a typical and vexed example - that Bruegel's Adoration of the Mag 2 (plate 20) ${ }^{69}$ hung in a secular context, and had no ostensible ritual function, it is still probable that the individual beholder would have responded to it in terms of the associations which this particular religious subject was capable of arousing, irrespective of its context. We have, therefore, to consider not only the intended and recognized function of an image - its manifest function - but also its unintended and unrecognized function, which we may call latent, to borrow a distunction used in the now classical analysis of functional explanation by R.K. Merton. ${ }^{70}$ What this implies, of course, is that one cannot speak in terms of a single meaning for a particular image; most art historians will have learned that its meaning may be modified according to its immediate context, and this is perhaps too obvious to need elaboration here. But what I would like to add is that it can also retain elements 
of 1ts meaning in other contexts. This is why apparently decorative images, as in the case of Madonnas in Flower Garlands, may still retain traces of their original religious function. ${ }^{71}$

All this contributes to the difficulty of interdiction. Let us turn again to one of Pieter Aertsen's many paintings of Christ in the House of Martha and Mary (plate 7) of the kind which so irked Erasmus, as well as Molanus. ${ }^{72}$ At first sight it seems nothing more than the representation of a kitchen scene, with an extensive depiction of vegetables and meat. But recent research has proved that the real meaning of the picture is to be found only when one takes the trouble to look into the background. ${ }^{73}$ The clear implication of the scene of Christ in the House of Martha and Mary is that one is not to be diverted from faith (the 'one thing needful' in the biblical account of the scene), nor from amor del, by sensual distraction, amor carnis. ${ }^{74}$ In addition, it has been sug. gested that the painting implies a recommendation of the contemplative life over the active one - Martha being the personification of the latter, and Mary (who chose the good part, the 'one thing needful' of Luke 10,38) of the former. ${ }^{75}$ Similarly, in one of Aertsen's most typical scenes (plate 23) ${ }^{76}$ an amorously engaged couple is set amidst a great quantity of market produce, their actions stressed by the presence of the birds whose symbolic connotations are now well known. But the moralistic point, as one comes to expect, is made by the scene in the background - predictably of Christ and the Adulterous Woman. What kind of picture is this, we may now ask ourselves, and what would the censors have made of it? If they objected to its lascivious imagery, then the point could always have been made that it had, in fact, a moralistic intention, perfectly in accordance with Christian dogma. And if it hung in a tavern - or dining room - then it would have served that purpose even better.

Although pictures like these, with the religious subject placed well into the background of abundant kitchen and market scenes already begin to be produced in the $1550 \mathrm{~s}$, it is in the $1560 \mathrm{~s}$, in the very decade of 1conoclasm, that they enjoy their greatest vogue. Could it be that these apparently secular paintings were felt to be less subject to Protestant attack, even to damage and destruction, than straightforward religious subjects? ${ }^{77}$ The ways in which accepted definitions of the borderline between sacred and profane were capable of modification provide some of the major clues to the ineffectiveness of interdiction, whether Protestant or Catholic.

Bruegel's painting of The Woman Taken in Adultery (plate 22) ${ }^{78}$ unlike Aertsen's, presents a different and more difficult kund of problem. If, as seems possible, it was intended to be read as a plea for tolerance, ${ }^{79}$ then this kind of meaning can only be discovered by the use of the biblical story as a symbol of tolerance in other literary or visual contexts; and its meaning could not have been defined as such, as a plea for tolerance, outside a curcle (of which Bruegel may have been part) to whom such an idea would have been important or sympathetic. Otherwise its meaning would have remained on the level of the manifest, and would certainly have been immune from charges of heterodoxy. A similar problem is raised by the great picture of the Carrying of the Cross (plate 21). ${ }^{80}$ It may be that there are Anabaptist allusions here - which seems unlikely, despite the efforts of certain scholars to discover them ${ }^{81}$ - but 


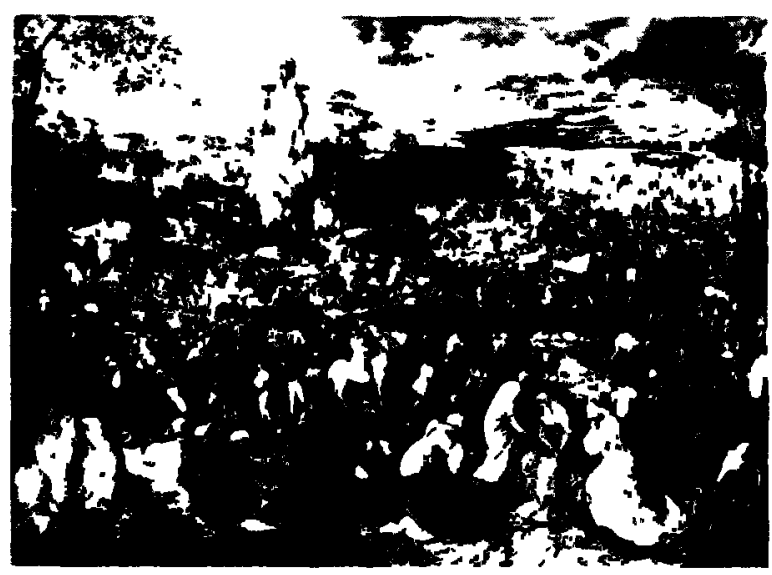

22 Pieter Bruegel the Elder, The Woman Taken in Adultery. London, Courtauld Institute of Art

Gallenes, Prince's Gate Collection. $24.1 \times 34.4 \mathrm{~cm}$.

23. Pieter Aertsen, The Woman Taken in Adultery. Stockholm, Nationalmuseum. $122 \times 180 \mathrm{~cm}$
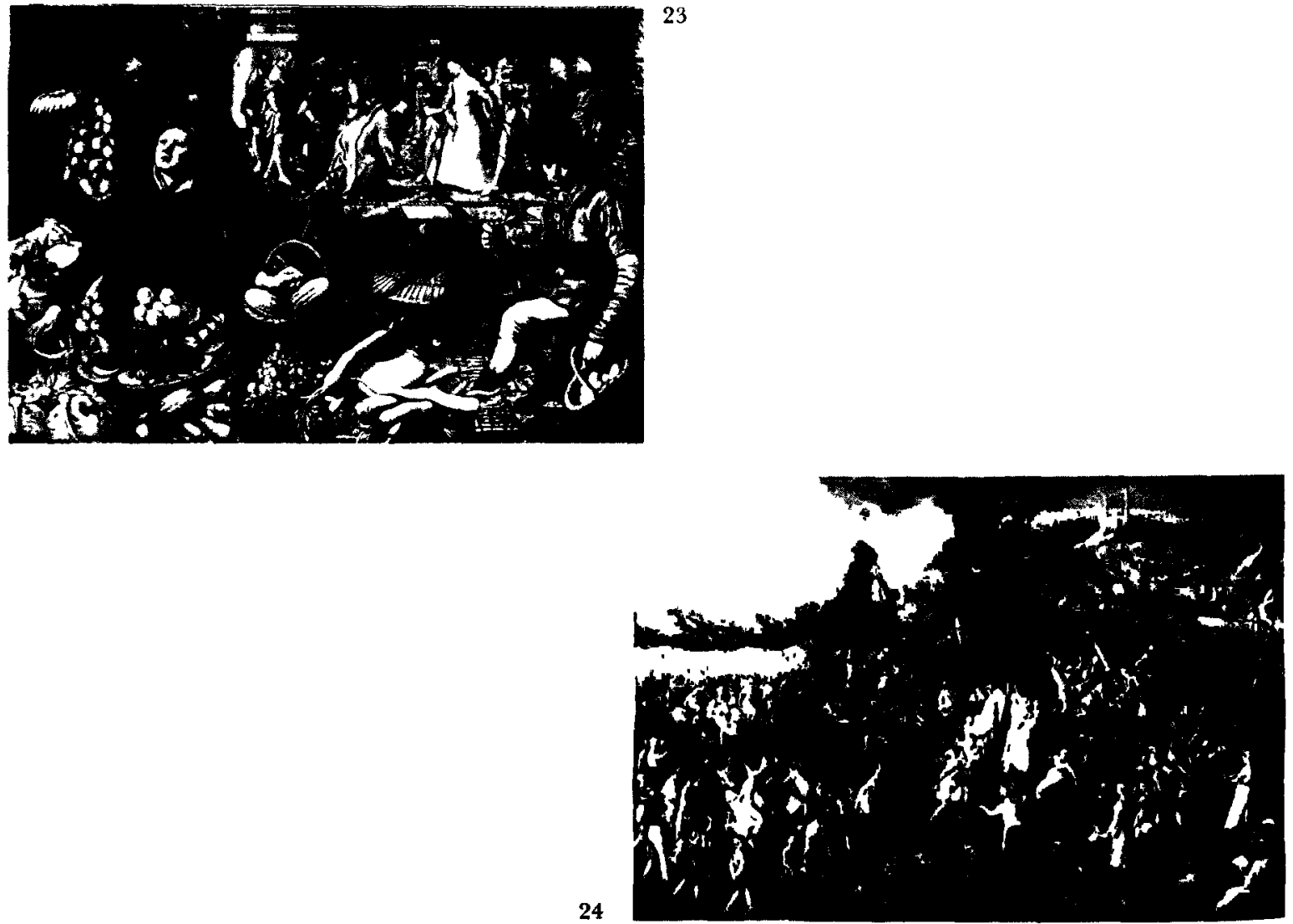

24 Pieter Aertsen, The Road to Calvary, 1552

Formerly Berlın, Gemaldegalerıe, destroyed, 1945 $77 \times 116 \mathrm{~cm}$

25 Henri met de Bles. The Road to Calvary

Princeton Universitv Art Museum $1143 \times 822 \mathrm{~cm}$

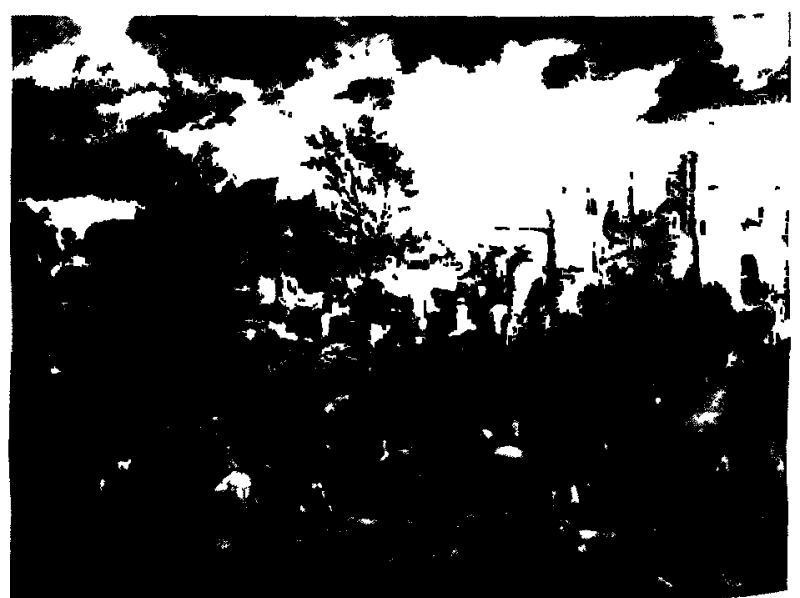


when it looked so obviously similar to other pictures of the same subject at the time, such as several paintings by Pieter Aertsen (plate 24) ${ }^{82}$ and the many paintings of the mysterious Brunswick Monogrammist and Herri met de Bles (plate 25$)^{83}$ then it must have been capable of having the same relatively straightforward meaning as they had. ${ }^{84}$

Paintings like these have been discussed - perhaps too elliptically - because they highlight some of the main problems of arriving at a more precise analy sis of the status of images in the sixteenth century. It is clear that images may have both a manifest and a latent meaning, according to their context, and to some extent a hidden, subconscious one as well. But Victor Turner has defined two further kinds of meaning which are of some relevance to a study of the kind suggested here. ${ }^{85}$ The operational meaning of a symbol - what we have called its function - is derived from the use made of the sy mbol, the social composition of the groups responding to it, and the affective qualities of the symbol in terms of the rituals or other social processes associated with it, while the positional meaning is constituted by the relationship of the simbol to other symbols in the total social or ritud system. In any given context, as we have seen, only a few of the meanings of a polysemous symbol may be stressed. ${ }^{86}$ What this paper has tried to suggest are the ways in which a sy mbol may none the less generate associations from its use in other contexts; or, as Turner put it, that the latent and to a certam extent the hidden meanings of a dominant sy mbol in one context may be discovered by using ex egetic reports on its significance in another. ${ }^{87}$ While the main aim of the art historian mal as well be to discover dominant meanings, it is only by taking into account the potential fluidity of meaning that he can define more preciselv the status of an image, and - incidentally - account for the fallure of interdiction. ${ }^{88}$

I have discussed the matter of attempted interdictions and some kinds of images produced contemporaneously with them in order to show how the Durkhermian distinction between sacred and profane mas be capable of modification according to function and context. But this is not to say that the distinction is too blunt to be of use. Durkheim himself never held that the distinction was fixed, and he devoted some attention to the matter of the contagiousness of the sacred, ${ }^{89}$ in ways that may be exemplified by sereral of the images referred to in this paper and by the responses to them. In any case, his system was not intended as a means of classifving objects, but rather of explaining the polarities of social consciousness - the polarities, it should be emphasized, and not the merging clements of the spectrum I have also examined the implications of the fusion of image and prototi pe, both by those who were in favour of images and those who were against them, to show that although for the purpose of analysis it may be best to separate sign and signified, they are liable to amalgamate, sometimes with quite dramatic consequences, in both the psychological and the social sphere. The matter of interdiction itself strikingly demonstrates the problem of confronting the fluidit of the signified when it is conditioned by the status of the sign.

It will perhaps have been observed that the first part of the title of this paper has been used at least twice before. Apart from Hubert Schrade's study of the representation of God in Israel and the Ancient Orient - Der 
Verborgene Gott Gottesbild und Gottesvorstellung in Israel und im Alten Orient - which provides the basic material for some of the theological underpinnings of Western attitudes towards images, ${ }^{90} \mathrm{I}$ refer, of course, to Lucien Goldmann's masterly description of the vision of God in the work of Pascal and Racine, entitled Le Dieu caché..$^{91}$ Although Goldmann's hidden god is an entirely different phenomenon from that described here, the approach to cultural artifacts - in the one case literary, in the other visual - proceeds from the same conviction. "The mode of behaviour which enables us to understand a particular work is not that of the author himself, but that of a whole social group. ${ }^{92}$ This claim is not a particularly novel one, and it has since been superseded by many refinements on the theme of the comparative inconsequence of authorial meaning. ${ }^{93}$ But historians of art have been unusually slow to attend to its nch implications, even though they have always made gestures in that direction. Works of art are not autonomous manifestations of the individual creative spirit, and to study them as if they were is to be careless of the material processes of history. Indeed, the artist's intention, the meaning which they had for him, may well not coincide with the meaning they acquire in their social context. This paper began with a discussion of iconoclasm and interdiction, and went on to discuss the problem of meaning, in order to show that it is possible for the historian to determine not only what an image was supposed to mean, or indeed, to be, but also what it actually meant to those who beheld it ${ }^{94}$ not only what the artist intended it to signify, but also what it signified in terms of the society for which it was made. Such issues are just as amenable to investigation as the more traditional forms of art historical analysis, whether iconographic, stylistic or functional, although the analy tic procedures may be different. Problems of response, particularly on the part of the unlettered, have tended to be regarded as incapable of anything other than sociological analysis, but this seems to me to take rather an ungenerous view of the possibilities of historical examination. The historian of images seems better equipped than most to deal with past data ${ }^{95}$ concerning the relations between material objects and socialized forms of perception: from the internal relations of images themselves he may arrive at conclusions not only about their status, but also about the ways in which they were perceived; from collective notions about what images are supposed to be and how they are supposed to work he may proceed inductively to reinforce the admittedly scattered historical evidence for effect and response - even in the absence of written testimony. There are dangers in turning from behaviour to cognition, or, indeed, in the a priort assumption of cognitive processes; but if he can turn from his traditional preoccupation with how images are made to the way they work it may no longer be necessary to justify the retreat into positivism on the grounds of the lacunae of the past.

David Freedberg Courtauld Institute of Art 


\section{NOTES}

Thıs paper was first presented as the first of the 1979 Baldwin Lectures at Oberlin College, Ohıo, which provided the opportunity to develop some of the ideas onginally presented in the articles cited in notes 1, 2, and 14. I am grateful to Willam Hood and Richard Spear for their helpful suggestions on that occasion, and to Sir Ernst Gombrich, Charles Hope and Elizabeth McGrath for their attempts to introduce some clanty into earlier versions of this paper Frances Carey and Antony Gnffiths drew my atten. tion to the important instances of censored engravings illustrated in plates $14-16$

1 See D. Freedberg, 'The Structure of Byzantıne and European Iconoclasm', in A Bryer and J Herrın, eds, Iconoclasm, Birmingham, 1977, pp. 165-77 for an outline of the general relations between Byzantine, medieval and later 1conoclasm. My 'The Problem of Images in Northern Europe and its Repercussions in the Netherlands', Hafnta, Copenhagen Papers in the History of Art, 1976, p 40 provides some more specific examples of the reutilization of earlier sources in the sixteenth century. See also notes $52-4$ below for the authorities named here.

2 E.g. in D. Freedberg, "The Representation of Martyrdoms in the Early Counter Reformation in Antwerp', Burlington Magazıne, CXVIII, 1976, pp. 128-38, and 'The Problem of Images' (see previous note), pp 25.45 The most recent general work on the Netherlands iconoclasm is J Scheerder, De Beeldestorm, Bussum, 1974, with good general bibliography.

3 'In has autem sanctas et salutares observationes sı qui abusus irrepserınt, eos prorsus abolen sancta synodus vehementer cupit', p. 775 in the reference cated in the following note

4 Decretum De invocatione, zeneratione et reliquins sanctorum et sacris imagınıbus (Sessio XXV), readily avalable in J. Alberigo et al., Conciliorum Oecumenicorum Decreta, Istıtuto per le Scienze Religiose, ed $3^{a}$, Bologna, 1973, pp. 774-6

5 See especially the important article by $\mathrm{H}$. Jedin, 'Entstehung und Tragweite des Trienter Dekrets uber die Bilderverehrung', Theologische Quartalschrift, CXVI, 1935, pp. 142-82 and 404-28

6 '. . . ita ut nullae falsı dogmatis imagines, et rudibus periculosi erroris occasionem praebentes statuantur. Quod si alıquando historias et narrationes sacrae scripturae cum id indoctae plebı expedıret, exprimı et figurarı contigerit, doceatur populus, non propterea divinitatem figurarı. .. Omnis porro superstitione in sanctorum invocatione, Reliquiarum veneratione, et imaginum sacro usu tollatur, omnis turpis questus elıminetur, omnis denique lascivia vitetur ita, ut procaci venustate imagines non pingantur, nec ormentur, et Sanctorum celebratione, ac Reliquiarum visitatione homines ad commessationes atque ebrietates non abutantur, quasi festi dies honorem sanctorum per luxum ac lascriam agantur' Decretum De . Imaginibus, in Conciliomum Oecumenicorum Decreta (see note 4), pp. 775-6.

7 For example, in the Christian Matrimonu Institutıo, in Desıderı Erasmı Opera Omnıa, ed J. Clericus (Jean Leclerc), V Leıden, 1706, col. $696 \mathrm{E}$. See also the comment by E. Panofsky, 'Erasmus and the Visual Arts', Journal of the Warburg and Courtauld Institutes, XXXII, 1969, pp 208-9. Cf also the passage cited in note 48 below

8 On the further implications of the example by Pieter Bruegel the Elder illustrated here (L. Lebeer, Beredeneerde Catalogus van de Prenten naar Pieter Bruegel de Oude, Brussels, 1969, no 30), see A Monballieu, 'De "Kermis van Hoboken” bij P. Bruegel, J Grummer en G. Mostaert', Jaarboek, Koninklijk Museum voor Schone Kunsten, Antwerpen, 1974, pp 139-71.

9 That fear is made explicit in the course of Veronese's interrogation before the tribunal of the Inquisition concerning his Feast in the House of Simon 'Do you not know that in Germany and in other places infected with heresy it is customary with various pictures full of scurrilousness and similar inventions to mock, vituperate and scom the things of the Holy Catholic Church in order to teach bad doctrines to foolish and ignorant people?' Translated by Elizabeth Gilmore Holt in A Documentary Historv of Art, II, New York, 1958, p 67 (Minutes of the Inquisition Tribunal of 19 July 1573, avalable in P Calıan, Paolo Veronese, Rome, 1888, pp $102 \mathrm{ff}$.).

$10 \mathrm{~F} \mathrm{H}$ Reusch, ed, Die Indices librorum prohibitorum des sechszehnten Jahrhunderts, Tubingen, 1886.

11 See H. Purenne, Historre de Belgique, III, Brussels, 1907, p. 351, and J Loosjes, 'De Invloed der Rederijkers op de Hervorming', Stemmen voor Waarherd en Vrede, XLVI, 1909, p 420

$12 \mathrm{G}$. Paleotti, Discorso intorno alle Immagin Sacre e Profane, Bologna, 1582, translated into Latin as De Imaginibus Sacris et Profanis .. Libn Quinque. Quibus mult iplaces eorum abusus tuxta sacrosancti Concily Tridentint 
decreta, deteguntur. Ac vanae cautiones ad omnium generum picturas ex Christiana Disciplina restituendas, proponuntur, Ingolstadt, 1594. On Paleott1 and the other Italian writers on art during the Counter Reformation, see the excellent article by $\mathrm{P}$ Prodı, 'Ricerche sulla teonca delle art 1 figurative nella Riforma Cattolica', Archir'o Italiano per la Stona della Plcta, IV, 1965, pp 121-212, and now too G Scairzz, 'La Teologia Cattolica e le immaginı durante il XVI secolo', Stona dell'Arte, XXI, 1974, pp 171-213

13 A select list is given in D. Freedberg, 'The Problem of Images' (see note 1 above), pp. 29 , 40 , and note 50 , further detals and additional authors in my DPhil. dissertation, "Iconoclasm and Painting in the Revolt of the Netherlands, 1566-1609', Unversity of Oxford, 1972, pp 68-96.

14 See D. Freedberg, 'Johannes Molanus on Provocative Paintings', Journal of the Warburg and Courtauld Institutes, XXXIV, 1971 , p. 229 , note 2 , for a brief biography and further bibliographic references.

15 The first (shorter) edition, however, bore the title De Pacturs et Imaginabus Sacris Liber unus, tractans de vitandis circa eas abusibus ac de earundem significationibus. The text cited in these notes will be Paquot's fully annotated edition of $1771 \mathrm{~J}$. Molanus, De Historia Ss. Imaginum et Picturarum pro vero earum usu contra abusus libri quatuor JN Paquot recensuit, illustravt, supplevit, Louvain, 1771 (henceforw ard Molanus)

16 In the furst place testimony is provided by the quite unusually large number of editions for a book of this kind, but see also the letter from Paleottı to Carlo Borromeo in 1579 already 'ho ritrovato 1 Molano de Prcturis onde non accadera che ella si scomodi di mandarmı il suo', quoted in Prodi, op c1t., p 137

17 For detalled exemplification of this aspect of Counter Reformation writing on the arts, see D. Freedberg, 'Johannes Molanus' (see note 14), pp. 229-45. An important discussion of earlier objections of this kind (omitted by me in the article cited here) is $C$. Glbert, 'The Archbishop on the Painters of Florence, 1450', Art Bulletın, XLI, 1959, pp. 75-87, especially pp. 76-80.

$18 \mathrm{See}$, for example, the Referemen van Anna $B$ ijns, ed A Bogaers and W L van Helten, Rotterdam, 1875, pp. 106, 118 and 124 for this species of critical challenge. Cf Martin Donk's similar acid suggestion that it were better to purify one's own home before worrying about the churches M Donk (Duncanus), Een Cort Onderscheyt tusschen Godlicke en Afgodissche Beelden, Antwerp, 1579 , B iv recto and verso ('Waerom en gaen wy niet sersten ons eygen huysen reyn maken van sulcke Afgoden over welcke wy macht hebben eeruy de kercken ontreynen en violeren'). See too Ronsard's bitter comments on the iconoclasts in the Discours des miseres de ce temps, in Oeurres complètes, ed P. Laumonier, IX, Pans, 1946, pp 179-84.

19 Jan Massys, Flora (Venus?), Stockholm, Nationalmuseum, no 507,M.J Friedlander, Early Netherlandish Painting, 14 vols, Ley denNew York-Washington, 1967-76 (henceforward Friedlander), XIII, no. 36, and Jan Massys, Judith, Antwerp, Konınklijk Museum voor Schone Kunsten, no 5076, Friedlander, XIII, no. 15. On the identification of the figure in the Stockholm picture, see J Held, 'Flora, Goddess and Courtesan', in De Artibus Opuscula XL. Essays in Honor of Eru'n Panofsky, ed M. Meiss et al., Neu York, 1961, pp 216-17 and note 86 .

20 In addition to the paintings cited in the previous note (the Stockholm picture is signed and dated 1561), see, for example, the Brussels Lot and his Daughters of 1565 , the Brussels Susanna of 1567, the Louvre Bathsheba of 1562 (illustrated in plate 5) and several Judiths - all illustrated in Fredlander, XIII, nos 11 , $14,13,15,16,17$, etc

21 Willem Key, Holy Family with the Infant St John, formerly Lucerne, Gallery Fischer, sale 26 June 1962, Friedlander, XIII, no 271a Cf the even more blatant treatment of this subject in the early painting by Jan Massys in the Art Museum, Carnegie Institute, Pittsburgh, Inv no 10-44, Friedlander, XIII, no. 27. See the following note for references to Molanus's views on the naked Christ Child.

22 Jan Massys, Bathsheba, Parns, Louvre, no. 2030B, Friedlander, XIII, no. 13, and Jan Massys, The Magdalene, formerly with Frohlich Vienna, Friedlander, XIII, no. 33. For Molanus's comments on all the subjects referred to here, see Molanus, pp. $122-3$ and 314 (the latter on the representation of the Magdalen, in the chapter entitled 'Maria Magdalena absque vestrum pompa pingatur', Lib II, Cap. XXV), and D. Freedberg, 'Johannes Molanus' (see note 14 above), pp. 238-9 for translation and notes on Molanus's objections to representations of the naked Christ Child.

23 Molanus, p 122, cf. Erasmus, Christzant Matrmonu Institutio, in Opera, V, cols $696 \mathrm{~F}$. $697 \mathrm{~A}$. On the relationship with the painting by Pieter Aertsen illustrated in plate 7 , see $P$ K.F. Moxey, 'Erasmus and the Iconography of Pieter Aertsen's Christ in the House of Martha and Mary in the Boymans van Beuningen Museum', Joumal of the Warburg and Courtauld Instıtutes, XXXIV, 1971 , p. 335.

24 Pieter Aertsen, Christ in the House of Martha and Mary, Rotterdam, Museum Boymans van Beuningen, Inv. no. 1108, dated 1553, Fredlander, XIII, no 307, Joachım Beuckelaer, 
Christ in the House of Martha and Mary, Amsterdam, Rijksmuseum, Inv. no. A1451. In the latter painting, however, Peter is not clearly inebriated, for a closer parallel to the Aertsen, one has to turn to Beuckelaer's painting of this subject in Stockholm, Nationalmuseum, no 323 (illustrated in P.K.F. Moxey, "The "Humanist" Market Scenes of Joachim Beuckelaer Moralızıng Exempla or "Slices of Life"?", Jaarboek, Konınklijk Museum voor Schone Kunsten, Antwerpen, 1976, pp 109-87, Fig. 46. Cf. the other paintings of this subject by Beuckelaer in Amsterdam, Rıjksmuseum, Inv. no. 2251 and by Aertsen in Vienna, Kunsthistonsches Museum, Inv. no. 6927 (dated 1552), Brussels, Musées Royaux des Beaux-Arts, Inv, no. 3754 (dated 1559), and formerly in Vienna, Galerie Lucas, 1935 (Fnedlander, XIII, nos 306, 308, 309). It seems to have escaped the attention of commentators on these works that the subsidiary scene with Peter amongst domestics sitting by a fire may well be an allusion to the scene in Mark 15, 67 and Luke 22, 55-6, where he warms himself by a fire. The moment is most explicit in the Brussels painting of 1559 listed above This plausible interpretation was first suggested to me by Professor Creighton Gubert.

$25 \mathrm{Cf}$. note 6 above and the opening sentence of the last paragraph of the Councll's decree 'Haec ut fidelius observentur, statuit sancta synodus, nemin licere, ullo in loco vel ecclesia, et iam quomodolibet exempla, ulla insolitam ponere vel ponendam curare imaginem, nisı ab episcopo approbata fuerit' (Conctliorum Oecumenicorum Decreta, ed. cit., p 776).

26 Molanus, p. 78 (Lıb. II, Cap. XXVII 'Puerpenum Beatae Virginis aegrotantis non esse pingendum') and pp. 83-4. Compare the identical objections expressed in the Summa Theologica by the Archbishop Antonino of Florence in 1450 (Not. III, tit 8, sec 4, cap. 11) cited in C. Gilbert, 'The Archbishop' (see note 17 above), pp. 76 and 81 .

27 Molanus, pp. 331-2; here he records simular objections by a variety of other writers, including Josse Chch thove and Johannes Eck. One wonders how, in the light of these comments, Molanus would have assessed the representations of this subject such as those by Hugo van der Goes, Joos van Cleve, and near contemporaries like Michael Coxcie (see the latter's little-known painting in the Musée de l'Assistance publique in Brussels).

28 P. Aertsen, The Adoration of the Magi (fragment of the wing of an altarpiece), Amsterdam, Rijksmuseum, Inv. no. A1909, Friedlander, XIII, no. 296. Cf. also plate 21, but the black magus is so common a feature of this scene in Netherlandish painting of both the fifteenth and the six teenth century that it seems surpnsing that Molanus should have gone to such lengths in his discussion of the matter. See Molanus, pp. 239-44.

29 R Campin (?), Detal of Annunciation (centre panel of the Mérode altarpiece), New York, Metropolitan Museum of Art, The Clossters. Molanus, pp 275-6. For Italian examples from the fourteenth century, see D. Robb, The Christ Child in Devotional Images in Italy durng the Fourteenth Century, New York, 1954, p. 189. For the objections in the Summa Theologica of the Archbishop Antoninus, see C Gilbert, 'The Archbishop' (see note 17 above), pp. 76 and 80 (with one later example added to those of Robb).

30 Pieter Bruegel the Elder, The Resurrection, Rotterdam, Museum Boymans van Beuningen, Inv no 121 , pen and brown ink with grey wash , $431 \times 409 \mathrm{~mm}$.

31 Molanus, pp 82 and 460 (where Josse Clichthove is again invoked). Strictly speaking, however, Bruegel's composition is a conflation of the Resurrection with The Maries at the Tomb of Chrst, a subject in which it is more usual to show the stone thus rolled away from the mouth of the tomb.

32 P Aertsen, The Seven Joys of the Virgin and The Seven Sorrows of the Virgin (both centre panels of altarpieces), St Leonard's, Léau (Zoutleeuw), Fredlander, XIII, nos 295 and 294 Molanus, p. 93 'sic etram ex simplici \& populari devotione pinguntur Septem Dolores \& Septem Gaudia Manac Virgınıs'. Cf. his criticism of Erasmus's mocking references to the Seven Sorrows of the Virgin, amongst several subjects (1bid , p. 90). It is perhaps worth commenting here on the rapid disappearance of this pair of subjects in painting from the latter half of the sixteenth century on, although it continued to be represented, less surprisingly, in prints such as those by the Wierix brothers (M. MauquovHendnckx, Les Estampes des Wierix, I, Brussels, 1978, nos 771-5)

33 'Quae commun quodam consensu receptae sunt' (Molanus, p. 90, cf also p. 93, 'quaedam magis ex populan \& simplici devotione pinguntur, quam ex solidis vel Scripturis vel Patrum testimonis', with a similar sentiment again on p. 319).

34 Molanus, pp. 319,330 For the view that subjects like thest (and many others) could be accepted on the grounds that they were probable, even though apocryphal, see Lib. II, Cap. 28 'Circa imagines quae errorem continent non periculosum quid tolerandum cavendumque sit ' Here Molanus expresses his disapproval of the Legenda Aurea (rather, he says on p. 84, the 'Legenda Plumbea'), but refrains from wholly condemning it 'nam quaedam ex apocryphis sumpta aliunde habent probabilitatem' ( 1 bid , p. 89 , cf. on the 
following page, 'Multa in picturis \& imaginibus esse toleranda, que probabilia sunt apud doctos quosdam aut vulgum')

35 Ibid., p. 93 The passage is a telling instance of Molanus's mode and approach 'Item Vulnera Christı per figuras Pedum, Manuum \& Cordis abscissorum, non quidem contra scriptura. os non comminuetis in eo (nam pictura haec non significat Christo os esse comminutum, aut abscissum. sed popularis, \& Deo non ingrata simplicitas, ita sibi proponit singularem Meditationem erga quinque benedicta Chnstı Vulnera.'

36 Ibıd., p. 14 See the references in the preceding four notes as well as several other passages in which he insists on caution and discretion in removing or correcting undesirable images Just as one tolerates certain things in speech so one should also tolerate them in paintings (p. 14), in correcting the abuses associated with images 'zeal is to be tempered by discretion' (p. 73), and so on.

37 See D. Freedberg, 'The Problem of Images', especially pp. $26-9$.

38 A.F. Blunt, Artistic Theory in Italy, 1450 1600, Oxford, 1968 (first ed. 1940), pp. 118-19 for a brief summary. R. de Maio, Michelangelo e la Contronforma, Rome-Barı, 1978 , especially pp. 1-63, has recently discussed at some length the contextual implications of objections to the Last Judgment, even from 1541 onwards See also L. Steinberg, "The Line of Fate in Michelangelo's Painting', Critical Inqutry, VI, 1980, pp. $411-54$, especially pp. $423-4$ and notes, and 'A Corner of the Last Judgment', Daedalus, Spring 1980, pp. 207-73, especially pp. 208-14 and notes for further illumination on the implications of criticism and attempted censorship of the frescoes in the Sistine chapel The matter of the covering up of the nudities receives detalled attention in $\mathrm{E}$ Camesasca, The Sistine Chapel, New York, n.d., I, pp. 248-50. A representative range of objections is of course to be found in G.A. Gilio da Fabriano's well known Dialogo deglı rrron de' pitton circa l'istona, Camerino, 1564 , reprinted in P Barocchi, ed., Trattatı d'Arte del Cinquecento, II, Ban, 1961, pp. 6-115.

39 In his letter of 1582 to the Accademici del Disegno in Florence, in G. Bottari and S. Ticozzi, Raccolta di lettere sulla pittura, scultura et archittetura . .., III, Milan, 1822, pp. 532-4, and now in P. Barocch1, Trattat d'Arte del Cinquecento, III, Ban, 1962, pp. 119-20

40 'Il che se è vero o non vero, non se ne aspetta 1 giudizio a me, basta che le figure che Sandro v1 fece, veramente sono da lodare, per la fatica che e e' durò nel girare 1 cerchı de' cielı, e tramezzare tra figure e figure d'Angelı e scorci e vedute in diversı modi diversamente, e tutto condotto con buono disegno' (Vasan, Le Vite - ed. G. Milanesı, 9 vols, Florence, 1878-85, III, 1878, p. 315 (sub Botticelli)). London, National Gallery, no 1126 , as 'ascribed to Botticinı' For the attempts to cover the work and place the chapel in which it stood under interdict, see A. Blunt, Artistic Theory (see note 38 ), p. 109.

41 Vasari-Milanesı, VI, 1881, pp. 535-6.

42 For several examples see D. Freedberg, 'The Problem of Images' (see note 1), pp. 29-31. The last paragraph of the Tridentine decree was quite explicit about ecclesiastical supervision and control, and its recommendations were repeatedly taken up by the provincial synods, as well as by all the theological writers on art.

$43 \mathrm{E}$ van Autenboer, 'Het Conclie van Trente en de Kunst in het Mechelse', in Studia Mechliniensia Bijdragen aangeboden aan $H$ Joosen ter Gelegenherd van zisn 65ste Verjaurdag, ed. A. Monballieu et al., Mechlın, 1976, pp. 219-29 gives good examples of local attempts at this kind of control in the first two decades of the seventeenth century, on the basis of the Mechlin diocesan Visitationes Decanales. See especially pp. 222, 225-6 and 228-9 for illustrations of the ineffectiveness of the instructions to remove or alter nuditates or imagines indecentes in local churches

44 See E Durkheim, The Elementary Forms of Religious Life, London, 1976 (1st ed. 1915) (henceforward Durkheim), p. 300. For 'taboo' see thescomprehensive critical examination by F. Steiner, Taboo, Oxford, 1956, as well as M Douglas, Puntv and Danger, An Examination of the Concepts of Pollution and Taboo, London, 1978 (1966).

45 Durkheim, p. 299.

46 Implicit throughout the furst chapter - "The Negative Cult and its Functions. The Ascetic Rites' - of Durkheim's book. Durkherm, pp. $299 \mathrm{ff}$

47 Cf. Durkherm, pp 301-2 for the separation of different classes of the sacred.

48 Implied by the passage from the Tridentine decree quoted in note 6 above, but see also Molanus, Lib. II, Cap. XXXIII ('Superstitionem omnem tollendam esse in sacrarum imaginum circumgestatione') and Cap. XXXIV ('Imaginum in Supplicatione circumgestatio a superstitione contra Haeretıcos defenditur'), pp. 95-8, as well as Erasmus in the Modus Orand , Opera (ed. cit), V, cols 1120A-1121B ('Rursum in publicis supplicationibus ac pompis ecclesiasticis, quantum videmus apud quasdam gentes superstitionis, unusquisque opificum ordo circumfert suos divos, ingentes mali portantur a multis sudantibus .. sunt enim ista vestigia paganısmi', etc. (tc)

49 See the passage translated by Molanus from Clement of Alexandria in Lib II, Cap. XLII ("In pictuns cavendumque esse quidquid ad 
Ibidınem provocat') 'Et rursum ad verba Clementis Alexandrinae presbyter, qui post acrem reprehensionem Paganorum, eo quod, in cubli decumbentes, Venerem nudam respicunt in tabellis depictis habeant quoque Paniscos, \& nudas puellas, \& ebrios Satyros, \& membrorum erectiones, quae Picturis nudantur, tandem concludit "Horum non solum usus, sed etram aspectus \& auditus, deponendam esse memorram vobis annuncramus"' (Molanus, p. 124, from Clement of Alexandria, Protreptikos, Cap 4, PG VIII, cols 161-2). Cf. also Molanus, Lib. II, Cap. LVII ('Quod Ethnicae Picturae \& Statuae non debeant Christianis placere'), although this chapter is not specifically concerned with nudity.

50 'Imagines porro Christı, Deiparae Virgınıs, et alıorum Sanctorum in templis praesertim habendas et retinendas, eisque debitum honorem et venerationem impertiendam, non quod credatur inesse alıqua in us divinitas, vel virtus, propter quam colendae, vel quod ab eis sit a alıquid petendum, vel quod fiducia in imaginibus sit figenda, velut 1 olım fiebat gentibus, quae in idolis spem suam collocabant, sed quoniam honos, qui eis exhibetur, refertur ad prototypa, quae illae repraesentant' (Conciliorum Oecumenicorum Decreta, p 775) The last point, made by every Counter

Reformation writer on images (and mocked by Calvin in Lib. I, Cap. XI of the Institution de la religzon chrétzenne (1560), especially sect. 10) derives from the famous passage from St Basil cited in note 54 below.

51 'Illud vero diligenter doceant episcopı, per historias mysteriorum nostrae redemptions, picturıs vel alıs sımılitudinıbus expressas, erudin et confirman populum in artıculıs fideı commemorandis et assidue recolendis . . quia Dei per sanctos miracula et salutana exempla oculis fidelıum subuciuntur, ut pro is Deo gratias agant, ad sanctorumque imitationem vitam moresque suos componant, excitenturque ad adorandum ac diligendum Deum, et ad pietatem colendam' (Conciliorum Oecumenicorum Decreta, p. 775).

52 The Gregonan position is made clear in the often cited letter to the Bishop of Marseilles (who had removed the images from churches in his diocese) 'Idcirco enim pictura in Ecclesis adhibetur, ut hi qui litteras nesciunt, saltem in panetibus videndo legant, quae legere in Codicibus non valent', in $P L$ LXXVII, cols 1027-8

53 Thomas Aquinas clearly articulated the three main functions of images in the following terms 'Fuit autem triplex ratio institutionis imaginum in ecclesia. primo ad instructionem rudium qui eis quası quibusdam libris edocent. secundo ut incarnat ionis mysternum \& sanctorum exempla magis in memona (ssent dum quotidic oculis repraesentantur. tertia ad 1 xcit- andum affectum quod ex visis efficacius incitatur quam ex auditis' (Commentanum Super Libros Sententiarum, Commentum in Librum III, dist. 9 , art. 2, qu. 2, a passage that is rarely correctly cited, and hardly ever actually quoted). This threefold division of the function of images appeared as a fundamental part of every justification of images from the Middle Ages on. Cf. Bonaventure's very sumilar formulation in his commentary on the Sentences of Peter Lombard 'Introductae enim fuerunt propter triphcem causam videlicet propter simplicium ruditatem, propter affectuum tarditatem \& propter memonae lablitatem. 1. ut sumplices qui non possunt scripturas legere in huusmodi sculpturis et picturis tamquam in scripturis apertus possint sacramenta nostrae fideı legere 2 ut homines qui non excitantur ad devotionem in his que pro nobis Christus gessit, dum illa aure percipiunt, saltem excitentur dum eadem in figuns et picturis tamquam praesentia oculis corpons cernunt. 3. 1deo dispensatione Dei factum est, ut imagines fierent praecipue in ecclesis, ut videntes eas recordemur de beneficus nobis impensis et sanctorum operibus virtuosis (Expositio in Quatuor Libros Sententiarum, Lıb III, dist. IX, qu. 2) The texts given here are based on a recension of the fifteenth-century editions in the British Library.

54 Hè tès eikonos timé ept to prōtotupon diabatner. The passage comes from St Basl's 1llustration of the relation of the Son to the Father in the Trinity in the De Spiritu Sancto XVIII, 45 (PG XXXII, col. 149C). It is discussed at some length in G. Ladner, 'The Concept of the Image in the Greek Fathers and the Byzantine Iconoclastic Controversy', Dumbarton Oaks Papers, VII, 1953, pp. 3-33, Cf. also E. Kitzınger, 'The Cult of Images in the Age before Iconoclasm', ıbıd, VIII, 1954, especially p. 91 .

55 Again the allegation is one of the commonest made against images in the Reformation and earlier. For the Netherlands, see for example the work attributed to the great polemicist Marnix van Sant Aldegonde, the Antwoorde P. Marnixı, Heere van St. Aldegonde, op d'assertie eenes Martinists, dat het afwerpen der beelden niemande dan der hoogher overhest gheoorlooft en $z \boldsymbol{\imath}$, printed in Philips van Mamix,

Godsdienstige en Kerkeligke Geschriften, ed J.J. van Toorenenberghen, 1, The Hague, 1871, p 27 , referring to images as 'plompe doode blocken ende steenen'.

56 The Bernardine position is set forth in the wellknown letter to Willam of St Thierry, Apologia ad Gullielmum Sancti Theoderici Abbatem, PL CLXXXII, cols 915-17, with its trenchant opposition of superfluous luxury in the adornment of churches to the real needs of the poor 'Fulget ecclesia in panetibus et in 
pauperibus eget. Suos lapides induit auro, et suos filıos nudos deserit. De sumptibus egenorum servitur oculis divitum'; and so on. Luther's attacks on misplaced splendour and nchness of church ornament are also frequently aligned with suggestions that the money spent in this way might better be expanded for more worth while social purposes, from his earliest works on see, for example, the Sermon on Indulgences in D. Luthers Werke, Kritusche Gesam tausgabe, Weimar, $1883 \mathrm{ff}$.

(henceforward $W A$ ), I, p. 236, and then $W A, I$, pp. 556, 598 (the poor are the living temples of God), $\mathrm{X}^{3}$, p. 82 (Sermon of 12 March 1522 , expressing the classic view that 'Man thet auch got kein dienst noch wolgefallen darinne wenn wir jm ein bilden machen, und theten besser, wann sie einem armen menschen einen gulden geben dann gotte ein gulden bilde', etc. etc.), and Br. X, p. 558 (letter to Count Ernest of Saxony) and many other places. For further references and discussion see now also $\mathrm{C}$. Chnstensen, Art and the Reformation in Germany, Athens, Ohı, 1979, especially pp. 42-65, and M. Baxandall, The Limewood Sculptors of Renatssance Germany, New Haven and London, 1980, pp. 88-93 (with an interesting selection of the views of Zwingli and some of the lesser Reformed writers).

57 Cf. Durkherm, p. 113 ("the totem is not merely a name; it is an emblem, a veritable coat of arms whose analogies with the arms of heraldry have often been remarked'), and especially p. 206. On p. 205 Durkheim asserts that 'it is obviously not out of the sensations which the things serving as totems are able to arouse in the mind that men have been led to 'construct the idea' of totemism. Art histonans have yet to ponder the implications of this point of view for a history of art that has so often excluded run-ofthe-mill images from its consideration (Durkheim's insight here seems to me to be unimpugned by the subsequent discrediting of the whole concept of totemism).

58 The major complations are Caesanus of Heisterbach's Dialogus Miraculorum and the Libr VIII Miraculorum (accessible in the editions edited by J. Strange, 2 vols, Cologne, 1851 , and A. Meister, Rome, 1901 respectively) and Gautier de Coincy's highly influential Les Mrracles de Notre Dame (the handiest edition is that of V.F. Koenig, 4 vols, Geneva, 1955-70 (Textes littératres francaus, nos 64, 95, 131, 176), which were much adapted in the fifteenth century. For the fullest treatment of these compilations, their ongins, and the other complations to which they are related, see $A$. Mussafia, 'Studien zu den mittelalterlichen Marienlegenden', Sitzungsberchten der Phil.hist. Classe der K. Akademie der Wissenschaften in Wien, CXIII, pp. 917-94, CXV, pp. 5-92, CXIX, Abh. 9 ; CXXII, Abh. 8, and CXXXIX,
Abh. 8, Vienna, 1886-96. See also A. Mussafia, 'Uber die von Gautier de Coincy benutzten Quellen', Denkschriften der K. Akademie der Wissenschaften, Phil-hist. Classe, XLIV, Vienna, 1896 I am in the course of preparing a study of the art histoncal implications of these and the other collections of miracle legends.

59 Very good examples are recorded in the case of the Anabaptist iconoclasm in Munster in $1534 / 35$, see M. Warnke, 'Durchbrochene Geschichte? Die Blldersturme der Wiedertaufer in Munster, 1534/35', in M. Warnke, ed., Bildersturm, Die Zerstorung des Kunstwerks, Munich, 1973,pp. 65-98, especially sections 6 ('Die Angriff auf die Herrschaftssymbole') and 7 ('Deformationsformen').

60 David Hume, The Natural History of Religion, in Essays Moral, Political, and Literary, ed. T.H. Green and T.H. Grose, II, London, 1889 , Section III, p. 317

61 S Freud, Totem and Taboo Some Points of Agreement between the Mental Lives of Savages and Neurotics, London, 1960 (1st ed 1913), p. 77.

$62 \mathrm{~J}$. Collaert after $\mathrm{M}$ de Vos, The Creation of Eve (from a set of 13 engravings representing the Creed of the Apostles), plate 14 published by A Collaert, plate 15 published by C. Visscher The altered plate illustrated as plate 15 here presumably came from a seventeenth-century Dutch Bible or cycle of Biblical scenes, such as those which were put together in great numbers under the auspices of $C$. Visscher, but I have been unable to identify the precise edition. These examples come from the Pepys Library, Magdalene College, Cambridge, as do further similar cases, such as the altered plates showing the Resurrection of the Flesh and the Heavenly Caty from the same cycle after Martin de Vos, where the representation of God the Father has also been removed (A.W. Aspital, Catalogue of the Pepys Library at Magdalene College Cambrige, Woodbridge (Suffolk), vol. III, pt i, 1980 , nos 388 (the plates llustrated here, 401-3, 404-5)

63 J. Collaert after J. Snellinck (?), The Seven Days of Creation, engraving (A.W. Aspital, cat. cit., no. 488 , as 'Anonymous').

64 Amsterdam, Ryjksmuseum, Inv. no. A 3841 , painted around 1530. Published and discussed by $\mathrm{N}$ Beets, 'De Dans om het Gouden Kalf. Een hervonden triptiek van Lucas van Leyden', Oud-Holland, LXVII, 1952, pp. 183-200. See D. Freedberg, 'The Problem of Images' (see note 1) p. 35 and note 91 for further references to works which cast some light on the Iconography - not yet fully explained - of this work. P. Parshall, 'Lucas van Leyden and the Rise of Pictonal Narrative', PhD dissertation, University of Chicago, 1974 has an illuminating discussion of this work within the context of Lucas's output as a whole. 
65 El Esconal (Museos Nuevos, Pinacotheca). See R.A. Koch, Joachim Patınir, Princeton, 1968 , Cat no 18.

The same elusiveness of definition and status applies to the many other sixteenth-century Netherlandish paintings showing St Christopher in an extensive landscape. It is true that one would not want to claim a significant devotional element for any of these works, but certainty is undermined by the not inconsiderable number of fifteenth-century works where similarly represented scenes do occur in devotional contexts, even if on the side panels of altarpieces (as in the case of the 'Pearl of Brabant' altarpiece in Munich, Alte Pinakothek, no. H.G. 78) But cf. p. 141 above for a further discussion of the problems of definition.

66 Stockholm, Natıonalmuseum, no. 321 For a brilliant discussion of the painting by Beuckelaer and the kind of reading it requires, see J.A. Emmens “"Eins aber ist notig" - Zu Inhalt und Bedeutung von Markt - und Kuchenstucken des 16 Jahrhunderts', in Album Amicorum J.G van Gelder, ed J Bruyn et al., The Hague, 1973, pp 93-101, now reprinted in $J A$. Emmens Verzameld Werk, 4 vols, Amsterdam, 1981, pt 4

(Kunsthistorische Opstellen, II), pp. 189-221. For an opposing interpretation see the article by Moxey cited in note 24 above, where a number of other paintings by Aertsen and Beuckelaer combining religious subjects like the Ecce Homo with extensive market scenes are illustrated. There seems little doubt, however, that they all carry a similar moralizing point Imitate Christ, do not be seduced by the amor carnts, nor, indeed (In the case of Beuckelaer's Ecce Homo with Fish Market also in Stockholm, no 324) by excessive indulgence in the outward practices of the Christian faith (e.g. the eating of fish during Lent). This reading is supported by the scene of the Ecce Homo - or a similar one - in the background. The same applies to the many related scenes by $\mathrm{P}$ Aertsen, on which see more on p. 142 above and notes 72 and 73 below For a strong statement of the moralizing view, see also A. Grosjean, 'Toward an Interpretation of Pieter Aertsen's Profane Iconography', Konsthistorisk Tidskrtft, XLIII, 1974, pp 12143.

67 London, Courtauld Institute of Art Gallenes, Prince's Gate Collection, Inv, no. 6.

68 For further comment, see p 142 above and note 79 below.

69 London, National Gallery, no. 3556, signed and dated 1564 .

70 R.K. Merton, Social Theory and Social Structure (revised edition), Glencoe, Illinoss, 1957. See the important modifications to this view of functional explanation by M. Spiro, 'Religion Problems of Definition and
Explanation', in M. Banton, ed, Anthropological Approaches to the Study of Religion (ASA Monographs 3), London, 1978 , pp 108-9, with further bibliographic references

71 Elaborated in D Freedberg, 'The Origins and Rise of the Flemish Madonnas in Flower Garlands Decoration and Devotion', Munchner Jahrbuch der Buldende Kunst, XXXII, 1981, pp. $135-50$

72 See $\mathrm{p} 135$ above and note 23

73 J A Emmens, " Eins aber ist Notig", (see note 66 above), p. 94

74 Ibid., p 95 Cf. also note 66 above.

75 Indeed, the passage from Luke 10 s excerpted in an inscription above the fireplace in Pieter Aertsen's 1552 painting in Vienna (Inv. no 6927, with the words 'Maria heeft utvercoren dat beste deel') and the inscription on the floor of Beuckelaer's 1565 painting of the subject in Brussels (Inv. no 782) also refers to Luke 10 . For other paintings of this subject, see note 24 above

76 Pieter Aertsen, Chrst and the Woman taken in Adultery, Stockholm, Nationalmuseum, no 2106, Fredlander, XIII, no 305 Cf the painting of the same subject bv Aertsen in Frankfurt, Staedelsches Kunstinstitut, no 1378 (signed and dated 1559)

77 The fate of religious paintings, by both Aertsen and Beuckelaer is recorded with considerable regret by van Mander. See, for example, C. van Mander, Het Schilder-Boeck, Haarlem, 1604, fols $238 v, 244$ and, especially, 244v, where he tells of how a widow of Alkmaar was unable to prevent the destruction of an altarpiece by Aertsen, despite the offer of 100 pounds to the iconoclasts in the hope of preventing them from proceeding further Van Mander also reports, significantly, Aertsen's own anger at the destruction of his works by the iconoclasts (fol. 244v)

78 Reference in note 67 , see too the following note.

79 The painting was first published by F. Grossman, 'Bruegel's "Woman Taken in Adultery" and other Grisalles', Burlington Magazine, XCN, 1952, pp. 218-29 Here Grossman notes that 'the grisalles, generally speaking, were produced by the artists either for themselves and their fellow artists or for their connoisseur friends', and suggests that thev may provide some evidence for the heterodox ideas held in Bruegel's circle (see, for example, A.E Popham, 'Preter Bruegel and Abraham Ortelius', Burlington Maguzine, LIX, 1931, p. 87), but he cautiously concludes that 'it would ... . be wrong to see in it a proof of Bruegel's secret Protestantism ( $s 2 c^{\text {? }}$ ) If we want to see in it more than a general plea for Chnstian chanty, we can at best interpret 1 as a penitent confession of human 
weakness. This, at least, would be in keeping with Ortelius's conviction.' But there remains a temptation to take the subject, emphasized by the inscription (from John 8) on the engraving after it (Lebeer, no. 88, 'Qui sine peccato est vestrum, primus in llam lapidem mit tat') and the vernacular equivalent written by Christ on the floor before the Pharisees ('Die sonder is die.. ') as indicative of those irenic news which we know were uidely held in Bruegel's circle at a time of considerable religious dissension and persecution. In Bruegel, The Paintings Complete Editıon, London, 1973 (3rd ed., revised), p. 196, Grossman is far more explicit, and claims that in the article mentioned above 'I tried to deduce both from the obvious meaning of the biblical story which is told in John VIII, 3-11, and by drawing upon Ortelius's letters that this grisalle has to be understood as a plea for toleration in the religious strife of Bruegel's time.'

80 Vienna, Kunsthistorisches Museum, Inv. no. 1025.

81 See especially M. Auner, 'Pieter Bruegel Umnsse eines Lebensbildes', Jahrbuch der kunsthistonschen Sammlungen in Wien, LII, 1956, pp 103-9. Apart from a series of hypotheses about lesser elements within the picture - the peddlers on the lower left, for example, being representative of the Wanderkramer of whom Auner says 'In der Geschichte des niederlandischen Taufertums spielen sie eine bedeutsame Rolle. Sie sind die eigentlichen Sendboten des Taufertums' the central suggestion is this 'Der Christus der Wiener Kreuztragung wird erst aus der Christologie des Taufertums aus dessen Lehre von der Menschhelt Chrıstı verstandlich. Diese Lehre vom menschlichen Christus, der in seiner Armut und Erniedrigung verlassen war bis in der Tod, hat dem Taufertums eine so grosse Schlagkraft verliehen. Er allein 1st der wahre Christus, der Christus der Armen und bedruckten, im Gegensatz zum Reichtum und der weltlıchen Macht des falschen Christus' (p. 106). In any case, the central doctrine of Anabaptism - according to Auner - 'ist eine Lehre des Kreuzes. Ihm haben wir in seinem Leben, Leiden und Sterben zu folgen und in aller Trubsal bis zur Wiedergeburt mit ihm auszuharren' (p. 108). None of these arguments is conclusive.

82 This example is the painting formerly in the Kaiser Friednch Museum in Berlin, Gemaldegalene, no. 726, destroyed in the Flakturm disaster of 1945, Fredlander, XIII, no. 312 , dated 1552. Other examples by Aertsen include the one formerly with the Galene Sankt Lukas in Vienna (1553) and that presently in Antwerp, Koninklyk Museum voor Schone Kunsten, no. 862 (Fnedlander,
XIII, nos 309 and 311 , cf. also nos 314 and 315). There are several closely related examples by Beuckelaer as well, including those in the Wetzlar collection in Amsterdam (dated 1562) and in the Kunsthalle in Hamburg (dated 1563). All these paintings by Aertsen and Beuckelaer are reproduced by D. Kreidl, 'Die rehigiose Malereı Pieter Aertsens als Grundlage seiner kunstlenschen Entwicklung', Jahrbuch der Kunsthastonschen Sammlungen in Wien, LXVIII, 1972, pp. 43-108, plates 48-52

83 'Herr1 met de Bles', Christ Carrying the Cross, Princeton University Art Museum, no 50-1. There are many extant examples of a simular treatment of this subject in paintings given to Herri met de Bles, such as those in Vienna, Akademie der Blldenden Kunst, and in Castagnola, Thyssen-Bornemisza Collection (Fredlander, XIII, no. 67). For the paintings attributed to the Brunswick Monogrammist in Paris (Louvre), Basle (Kunstmuseum), and the de Boer Collection in Amsterdam, see D. Schubert, Die Gemalde des Braunschwerger Monogrammist, Cologne, 1970, plates 6, 13 and 44, Cat nos 2, 4, 17. See also Schubert's excursus 'Zur Bildtradition der Kreuztragung' (pp 109-13) with further detals of the derivation of this form of representation from Van Eyck onwards

84 The same caution may be made with respect to subjects like The Preaching of St John the Baptzst and the Ecce Homo, drawing again upon the examples from the oeuvres of the Brunswick Monogrammist and Hern met de Bles.

85 In V. Turner and E. Turner, Image and Plgnmage in Christian Culture, New York, 1978, pp. 247-48. The appendix in which these classifications are proposed grows out of Turner's continuing preoccupation with the nature of symbolism, cf. his The Forest of Symbols, Ithaca, New York, 1967 for lengthier examination, as well as The Drums of Affliction, Oxford, 1968

86 Tumer and Tumer, Image and Plgrimage, p. 248 , cf also The Forest of Symbols, pp 50-1

87 Turner and Tumer, Image and Pigrimage, p. 248, but also pp. 244-7.

88 I do not think that the matter of fluidity of meaning is wholly resolved by the distinction between meaning and significance, what is required, perhaps, is refinement of the notion of associational range. Elsewhere I hope to examine the implications for the study of images of the view of meaning offered by $H$ P. Gnce, notably in 'Meaning', Philosophical Review, LXVI, 1957, pp. 377-89, a useful supplementary sketch is W.P. Alston, 'Meaning and Use', Philosophical Quarterly, XIII, 1963, pp. 107-124.

89 Durkhetm, pp. 222 and 319-25. 
$90 \mathrm{H}$ Schrade, Der Verborgene Gott Gottesbild und Gottesuorstellung in Israel und $2 m$ alten Onent, Stuttgart, 1949

91 L. Goldmann, Le Dieu caché Etude sur la vision tragique dans les Pensees de Pascal ct dans le théâtrc de Racinc, Parıs, 1955

92 Ibid, p. 7

93 The assault runs, as far as I can determıne, along four main paths (1) the phenomenological, (11) the semiotic, (111) the neo-marxian, and (11) that of modern hermeneutic theorv Endless permutations of these four approaches are possible, with frequent incursions into debates in ordinary language philosophy about speech act theory and the possiblity of synonymy Meaning began to be detached from the author and the possibility of stable meaning undermined as a result of the work of both Husserl and the later Wittgenstein, on wholly different grounds, but the most sustaned damage emerges from the work of H.G. Gadamer (see especially his Wahrhe it und Methode Grundzuge einer philosophische Hermeneutik, 3 erueaterte Auflage, Tubingen, 1972), sometimes from the work of Barthes and the other semioticians (views neatly summarized in J Culler, Structuralist Poetzcs, London, 1975), and in the literan hermeneutics of $H$ Jauss and
W Iser (especially now The Act of Re'ading $A$ Theory of Aesthetic Response, LondonBaltumore, 1978), both of whom have developed elaborate and suggestive theories of response to texts For a wholly intellectualized view of the sociological implications of the death of the author, see J. Wolff, The Soctal Production of Art, London, 1981 (with characteristic English neglect of the potential usefulness of Pierce and the Amencan pragmatic tradition) The most spirited modern defender of the validity of authorial meaning has been E.D. Hirsch, $\mathrm{Jr}$, in Valudity in Interpretation, New Haven, 1967, and The Aims of Interpretation. Chicago, 1970

$94 \mathrm{Th}$ is is not to espouse the notion of 'actual meaning' or even of the possibiliti. A clearlv desirable aim of the histonan of images must be to establish, as closely as possible, the associative range of particular images, but that task has yet to reach an adequate level of theoretical sophistication. Adverbial use here ('actually') does not imply either ease of attainment or of definition.

95 One could, of course, argue that he is - or should be - best equipped to deal with present data about these relations as $w$ ell, but that is another stor 